\title{
Protagoras and the beginnings of grammar
}

Luuk Huitink and Andreas Willi

\section{Summary}

Offering a reevaluation of all the available evidence, including passages from Aristotle's Rhetoric, Poetics, and Sophistici Elenchi, Diogenes Laertius' biographical sketch as well as the grammar scene in Aristophanes' Clouds, the article argues that Protagoras' engagement with grammatical questions must have been more sophisticated and thorough than is often assumed. In Protagoras' discovery of grammatical gender, formal considerations - most likely inspired by the analysis of personal names - played a more fundamental role than semantic ones, and his typology of $\pi v \theta \mu \varepsilon ́ v \varepsilon \varsigma \lambda{ }^{\prime} \gamma \omega v$ equally presupposes the formal recognition of at least verbal mood, if not also tense.

\section{Keywords}

Protagoras, Aristotle, Aristophanes, grammatical gender, verbal mood, verbal tense

\section{$1 \quad$ Introduction}

Four brief but intriguing passages from Aristotle and Diogenes Laertius are our best indication for Protagoras' interest in linguistic phenomena. The first two concern gender distinctions in nouns and congruence, while the other two are suggestive of Protagoras' interest in verbal mood 
(or so we will argue). Here are the passages as one can find them in modern collections of Protagoras' fragments: ${ }^{1}$

\section{Gender}

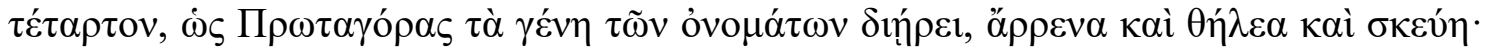

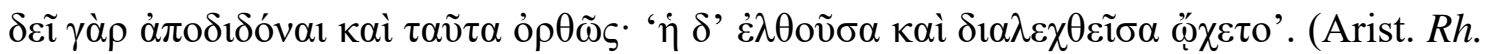
1407b6-8 = DK 80 A 27 = Radermacher B III 6 = Protagoras D23 Laks/Most)

A fourth [rule of correct usage or $\dot{\varepsilon} \lambda \lambda \eta v i \zeta \xi \varepsilon v$ is] Protagoras' distinction between the genders of nouns: masculine, feminine and 'things'. For one should correctly reproduce these distinctions too: 'Having come and having spoken, she left'.

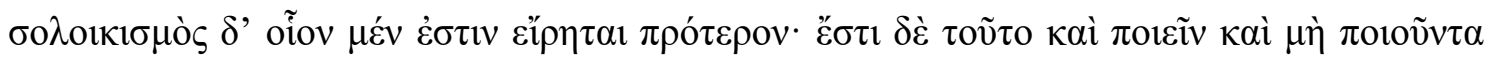

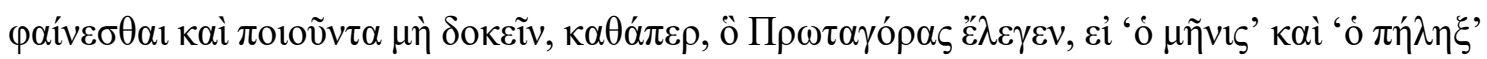

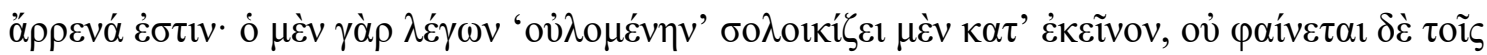

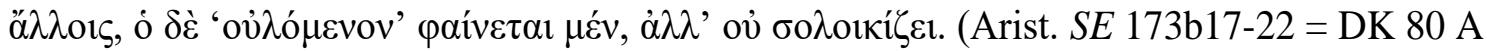
$28=$ Radermacher B III 7 = Protagoras D24 Laks/Most)

What sort of a thing a 'solecism' is has been said above. It is possible to commit one and to appear to commit one without doing so and to commit one without seeming to, as happens if, as Protagoras claimed, $\mu \tilde{\eta} v i \varsigma$ wrath and $\pi \eta \dot{\lambda} \eta \xi$ helmet are masculine. For according to him, someone who says 'destructress' (fem. oủ

\footnotetext{
${ }^{1}$ We print a bit more of the surrounding text than some of the collections; we will discuss relevant uncertainties in the text of DK 80 A 28 and A 1 below. Translations are ours; some of our choices are defended below.
} 
solecism, but he does not appear to do so to others, and someone who says 'destructor'

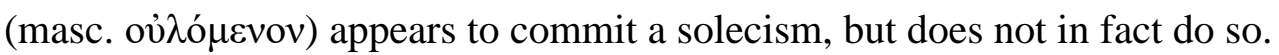

Mood

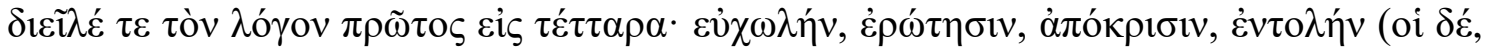

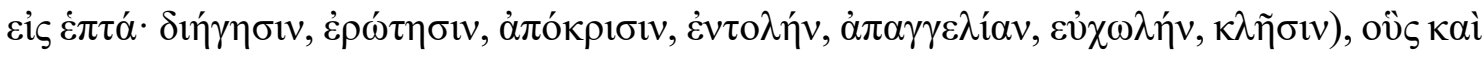

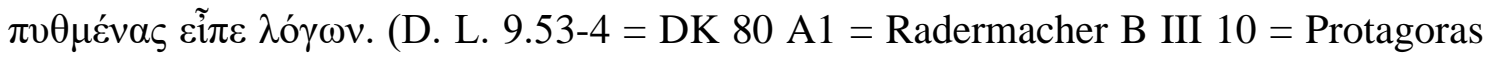
D17 Laks/Most)

He was the first to divide speech into four kinds - prayer, question, answer, command (others say into seven: narration, question, answer, command, report, prayer, calling), which he even named 'foundations of speech'.

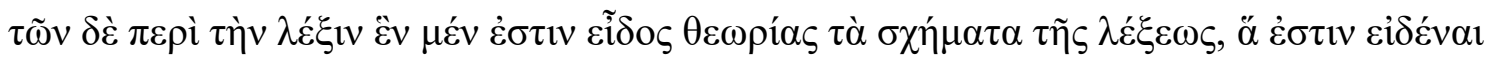

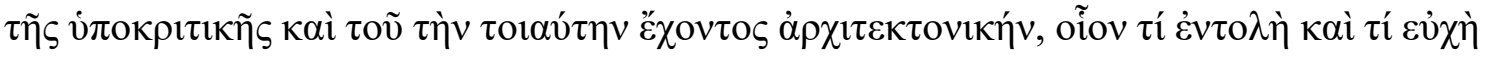

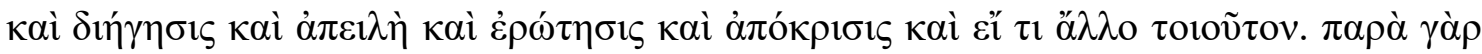

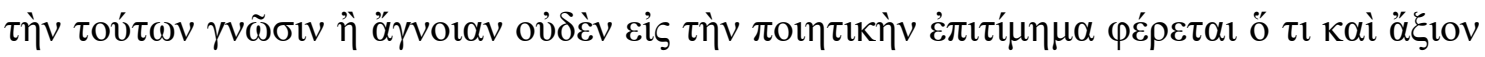

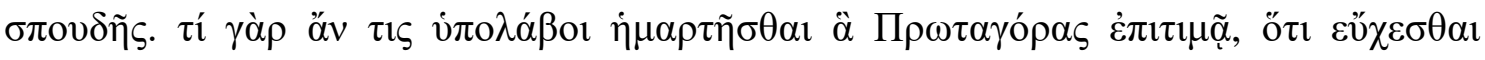

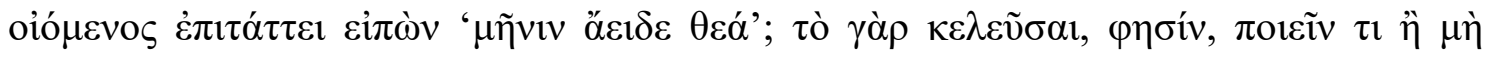

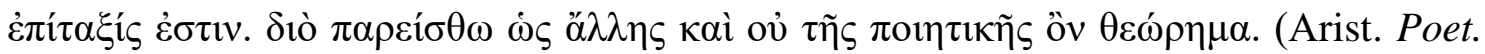
1456b8-19 = DK 80 A29 = Radermacher B III 13 = Protagoras D25 Laks/Most)

In matters of lexis, one kind of study concerns the manners of speaking. Knowledge of these belongs to the art of delivery and to anyone who has that kind of expertise; for instance, what a command is or what a prayer, a narration, a threat, a question, an answer 
or any other such matter. For no serious charge can be brought against the art of poetry on the basis of knowledge or ignorance of these matters. For why would one suppose that what Protagoras criticizes is a mistake, namely that [Homer], whilst thinking he is uttering a prayer, gives an order by saying, 'Sing, Muse, of the wrath?' For to command, [Protagoras] says, is to give the instruction to do or not to do something. Therefore, let this consideration be left aside as being the object of study of another art and not of poetry.

These two pairs of fragments suggest a similar pattern. First, Protagoras makes a global and seemingly uncontroversial distinction - between genders in nouns or between four (or seven) $\pi v \theta \mu \varepsilon ́ v \varepsilon \varsigma \lambda{ }^{\prime} \gamma \omega v$ - and then he applies those distinctions in an unexpected, provocative way,

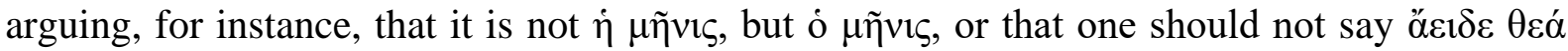
when uttering a prayer ( $\varepsilon v_{\chi}^{\omega} \omega \lambda \eta \dot{)}$. At the same time, many details remain to be clarified: it is not obvious what some of the terms used in these passages mean, nor why $\mu \tilde{\eta} v i \varsigma$ should be masculine or saying ő́t $\delta \varepsilon \theta \varepsilon \alpha ́$ be incompatible with uttering a prayer. Nonetheless, without being blind to the apparent normative slant of Protagoras' linguistic endeavours, Gomperz found these fragments impressive enough to credit the sophist with being the first to show a systematic interest in grammar. ${ }^{2}$

However, efforts to come to a more precise understanding of exactly what Protagoras was up to, were dealt a severe blow when Fehling (1965) argued that Protagoras' views of language did not amount to a systematic and independent body of early linguistic theory. Pointing out that two of the concrete applications of Protagoras' insights of which we have knowledge

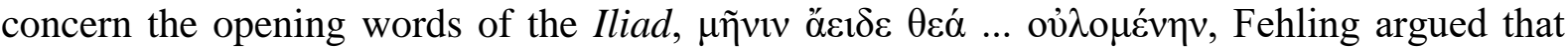

\footnotetext{
${ }^{2}$ Gomperz (1922) 365-9. Steinthal (1890-91) 1.136 called Protagoras' distinction between genders of nouns the 'Entdeckung der ersten grammatischen Tatsache', but added that because of Protagoras' remark on $\mu \tilde{\eta} v i \varsigma$ being masculine this discovery was immediately tainted 'mit dem Fluche der Lächerlichkeit'.
} 
Protagoras' linguistic observations were entirely ad hoc, and solely developed as an instrument for criticizing Homer and other poets. Fehling drew the conclusion

daß die grammatischen Einteilungen, die von Protagoras überliefert sind, nicht einer systematischen Abhandlung entstammen, sondern nur im Rahmen einer beispielhaften Vorführung seiner Methode der Dichterkritik und auch dort nur beiläufig entwickelt wurden. Es ist dann so gut wie sicher, daß es weitere Einteilungen von ihm nicht gegeben hat. (Fehling (1965) 214)

Fehling's view has won widespread acceptance, so that it is now quite generally thought that Protagoras' observations on language were 'casually' made (Schenkeveld (1984) 293), or a mere 'by-product' of his intellectual rivalry with Homer (Sluiter (1990) 8). Only recently have scholars begun to reconsider the sophist's contribution to linguistic thought, especially Corradi (2012) and Rademaker (2013). However, they continue to study Protagoras’ ó $\rho$ oć́ $\varepsilon \varepsilon 1 \alpha$ mostly in the context of what we know of the sophist's wider curriculum, as being relevant to his

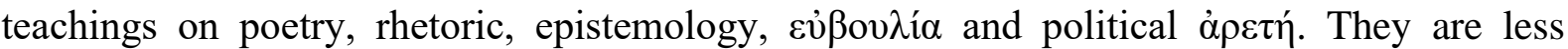
interested in reconstructing Protagoras' linguistic arguments, and are content with offering various possibilities.

In our view, Fehling's position deserves a firmer rebuttal than it has been given so far. We do not deny that Protagoras pressed his linguistic activities into the service of his critique of Homer, but we do not think that they can have been nearly so ad hoc as Fehling and others claim. Here is for good measure Fehling's reconstruction of Protagoras' argument, written in the sophist's voice:

'Ich will zeigen, wie man untersucht, ob ein Dichter etwas richtig gesagt hat oder nicht, denn der Menge scheint oft vieles ganz anders, als es in Wirklichkeit ist. Die Ilias wird 
von allen Griechen für die größte aller Dichtungen gehalten. Dennoch hat Homer bereits

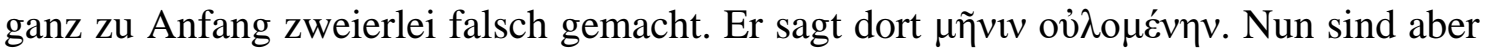
alle Substantive entweder männlich oder weiblich oder sächlich. Das Wort $\mu \tilde{\eta} v ı v$

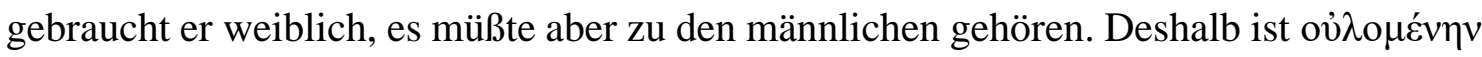
nur dem Anschein nach richtig, in Wahrheit wäre es aber oủ $\lambda o ́ \mu \varepsilon v o v$. Ferner sagt er $\alpha \_\varepsilon 1 \delta \varepsilon$

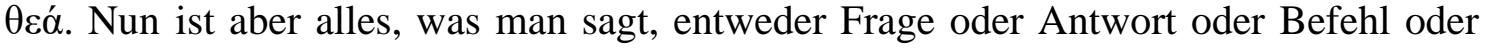
Bitte. ő $\varepsilon 1 \delta \varepsilon$ aber sagt man, wenn man befiehlt. Also hat Homer zwar geglaubt, die Muse zu bitten, in Wirklichkeit ihr aber befohlen.' (Fehling (1965) 214)

It seems to us that this reconstruction passes over a number of important points.

First of all, Fehling fails to acknowledge the pioneering character of Protagoras' observations, writing instead as if distinctions such as those between the genders of nouns could already be taken for granted by Protagoras and his audience. ${ }^{3}$ In fact, the passage from Aristotle's Rhetoric strongly suggests that Protagoras was the first to make gender distinctions in nouns, while Diogenes Laertius explicitly states that Protagoras was the first $(\pi \rho \tilde{\omega} \tau \circ \varsigma)$ to

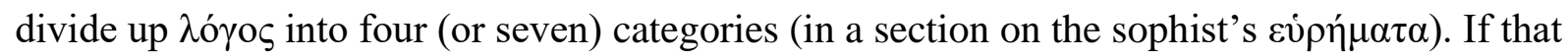
is so, the question is whether such distinctions can be 'casually' made without much argument or exposition. It is not immediately transparent, for instance, that the difference between ó $\dot{\eta} \tau o ́$ is one of gender (if, say, you ask a French child not yet schooled in grammar why it is 'la table' and not *'le table', the child would hardly say that it is because 'table' is feminine). And the same question becomes more pressing still when we also take into consideration that Protagoras was not only the first to make the distinctions attributed to him, but also made them in such a

\footnotetext{
${ }^{3}$ A more sympathetic attitude towards the importance of, and the difficulties involved in, Protagoras' raising awareness of linguistic facts is expressed by Gomperz (1922) 365-9, Wackernagel (1928) 4 and Dietz (1976) 67, 1534. Cf. Stern (1983) for a modern appraisal of the role of 'language awareness' in learning and teaching languages.
} 
way that he could put them in the form of normative 'rules' and convincingly maintain, against the Sprachgefühl of his fellow Greeks, that Homer made two mistakes in writing $\mu \tilde{\eta} v ı v ~ \alpha ̌ \varepsilon เ \delta \varepsilon$

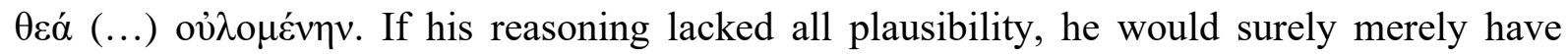
sounded ridiculous (as of course he does to Fehling and other modern scholars - it may be noted in passing that sounding ridiculous is different from being playful). All of this requires a more elaborate and sustained argument than is warranted by a wish to score a few easy points off Homer.

Secondly, if there is any historical accuracy in Plato making Protagoras proclaim, in the eponymous dialogue (Prot. 339a),

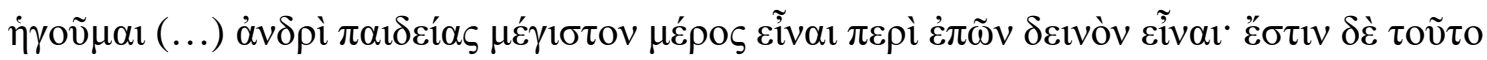

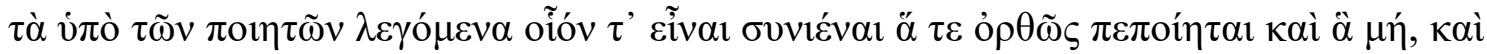

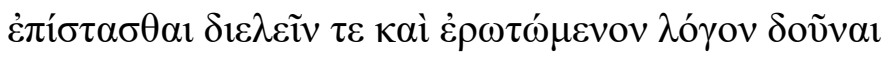

I believe the most important piece of education for a man is to be competent in poetry; and that means to be able to understand what is well formulated and what is not in what the poets say, and to know how to analyse these things and set them out when questioned,

it becomes rather difficult to imagine Protagoras charging his exorbitant fee of 100 minae (D.L. $9.52=$ DK 80 A 1) without giving detailed and reasoned guidance on how to proceed with the critical analysis that was meant to be the centrepiece of his curriculum. ${ }^{4}$

\footnotetext{
${ }^{4}$ The exact amount has been questioned, but is irrelevant; the fee-paying nature of the sophists' instruction is beyond doubt: for Protagoras cf. also Pl. Prot. 349a, Hipp. Mai. 282d, Isocr. Hel. 2 and 6, Philostr. VS 1.10, and see on the matter e.g. Blank (1985), Tell (2009).
} 
And thirdly, for what is is worth, we should note that the famous encounter of Strepsiades with 'Socrates' in Aristophanes' Clouds, which will be discussed more fully later on, unambiguously makes the 'Protagorean' study of grammar an independent and self-contained part of instruction. After Strepsiades has explicitly complained that all he wants to learn is the 'most unjust speech', he is sternly told by 'Socrates'(-Protagoras)

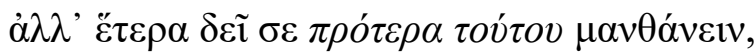

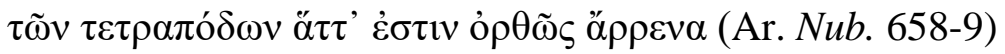

But before that you have to learn other things, which of the four-footed beings are truly male

— upon which a lengthy lesson on grammatical gender follows, which bears no humoristic resemblance whatsoever to what Fehling imagined to have taken place in Protagoras' classroom, but focuses exclusively on (comic) linguistics per se (Ar. Nub. 660-93; cf. Section 2.5).

In what follows, we will first make an attempt to reconstruct Protagoras' ideas about gender and then those about mood, before considering other grammatical distinctions which the sophist may have made.

\section{Protagoras on grammatical gender}

\subsection{Text and interpretation of Sophistici Elenchi}

As a first step towards reconstructing Protagoras' doctrine of gender, we need to consider the relevant passage from the Sophistici Elenchi more closely. Exactly what Aristotle says here is 
unclear and has led to confusion. One difficulty originates from a textual issue. The manuscripts

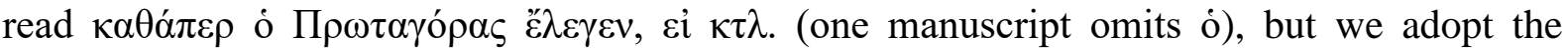
accentuation ô and accompanying punctuation proposed by Ross in the $O C T$. This correction brings the text in line with Aristotle's practice of not using articles with personal names when citing sources. ${ }^{5}$ It also makes it possible to take $\kappa \alpha \theta \alpha ́ \pi \varepsilon \rho$ and $\varepsilon i$ together, producing a phrase with which Aristotle regularly introduces (dubious) claims that serve as examples. ${ }^{6}$ An important consequence of construing $\kappa \alpha \theta \alpha \dot{\pi} \varepsilon \rho$ with $\varepsilon i$ rather than with $\check{\varepsilon} \lambda \varepsilon \gamma \varepsilon v$ is that it makes

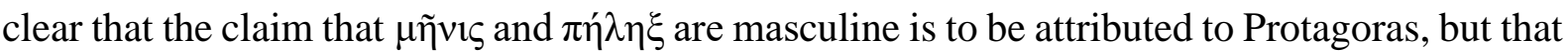
the distinction among three manifestations of solecism belongs to Aristotle himself. This is likely enough, because throughout the Sophistici Elenchi Aristotle is concerned with analysing the validity and invalidity of sophistic arguments (in casu those that involve grammatical errors) and the reasons why invalid ones often have a semblance of validity about them. ${ }^{7}$

\footnotetext{
${ }^{5}$ The article is never so used in the Sophistici Elenchi, Poetics and Rhetoric, the works that have been checked

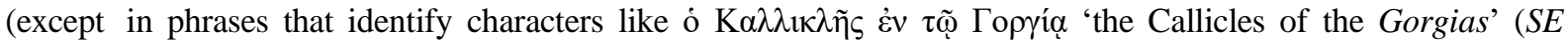
173a8)).

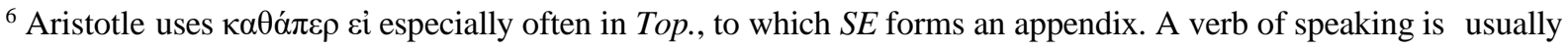
drawn into the $\varepsilon \dot{i}$-clause, but in our case the claim has actually been made and so é $\lambda \varepsilon \gamma \varepsilon v$ does not come under the

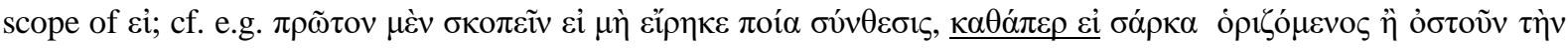

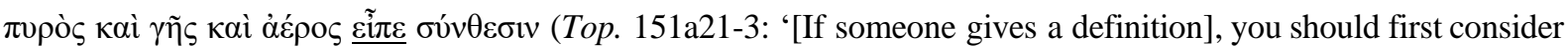
if he has failed to state the kind of composition; this [i.e. not stating the kind] is exactly what happens if someone in defining "flesh" or "bone" called them a "composition of fire, earth and air"").

${ }^{7}$ Translations such as those of Graham (2010) 2.709 ('there is a difference between committing this, not committing it but seeming to, and committing it but not seeming to, as Protagoras used to say. For instance "wrath" and "helmet" are masculine in sense [but grammatically feminine in Greek]') and Laks/Most (2016) 51 ('It is possible not only to commit one [i.e. a solecism], but also to seem to commit one although one does not do so, and also to commit one without seeming to do so, as Protagoras used to say, since "wrath" (...) and "helmet" (...) are [scil. in reality] masculine') obscure the matter as they attribute the typology of solecism to Protagoras and make
} 
With those bases covered, we turn to the question how Protagoras' claim that $\mu \tilde{\eta} v i \varsigma$ and $\pi \eta \dot{\lambda} \eta \xi$ are masculine relates to these three manifestations of solecism. In our view, two possibilities are worth considering. For our first explanation, it is important to keep in mind that in the Sophistici Elenchi Aristotle critically reviews types of invalid, but seemingly plausible, arguments used by sophists when they attempt to refute an interlocutor in a question and answer session ('̌ $\lambda \varepsilon \gamma \chi 0 \varsigma) .{ }^{8}$ The first type of solecism identified by Aristotle ('to commit one') is not, it seems, exemplified. It provides the base line, so to speak, and merely concerns mistakes committed against common usage which are recognized by everyone. By contrast, the other two types may both be illustrated in the sentence headed by ó $\mu \dot{\varepsilon} v \gamma \grave{\alpha} \rho \lambda \varepsilon \dot{\varepsilon} \gamma \omega \mathrm{v}$, though not straightforwardly so, because after Aristotle's opening statement on there being three manifestations of solecism, the perspective shifts to that of Protagoras (note $\kappa \alpha \tau$ ' $\dot{\varepsilon} \kappa \varepsilon i v v o v$, which distances Aristotle from Protagoras' claim). ${ }^{9}$ The sentence may thus be read as a compressed

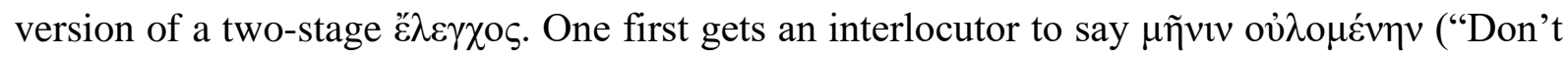
you think the first lines of the Iliad are particularly fine? Can you recite them for me?") and then states that the interlocutor is wrong to say it ("You thought they were fine? Now that I come to think of it, there's a huge mistake in them, which you just unthinkingly reproduced"). The sophist next leads the interlocutor through an argument which makes it seem plausible that

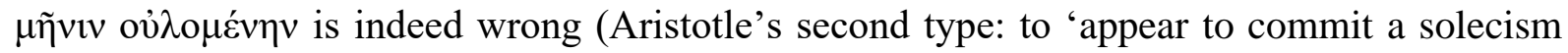

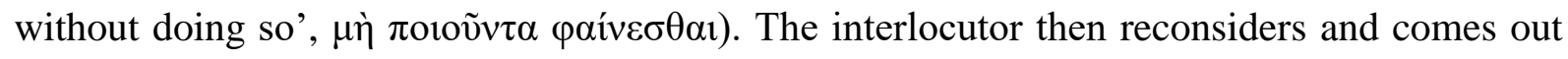

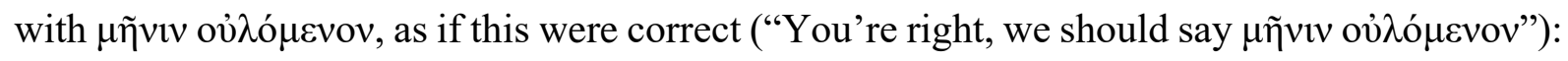
he now commits a solecism, but no longer seems to do so (the third type: to 'commit a solecism,

\footnotetext{
it seem as if the idea that $\mu \tilde{\eta} v i \varsigma$ and $\pi \hat{\eta} \lambda \eta \xi$ are masculine derives from Aristotle. Hecquet (2019) 221 is more precise ('il est possible d'en faire, et de paraître en faire sans en faire, et de ne pas sembler en faire quand on en

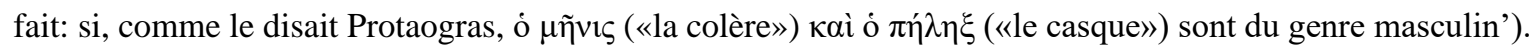

${ }^{8}$ Cf. Dorion (1995) 15-24 for an in-depth analysis of the title in relation to the content of the treatise.

${ }^{9}$ Cf. Hecquet (2019) 221 n. 7, who suggests that the two types are illustrated 'sous forme de chiasme'.
} 


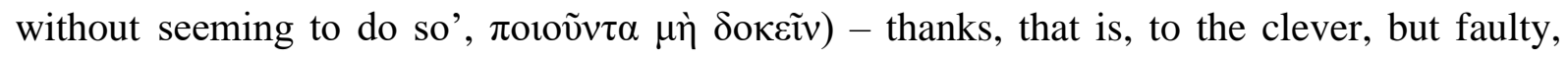
reasoning of the sophist, against which the Sophistici Elenchi teaches you to be on your guard.

The second way of reading the passage brings in the difference between $\varphi \alpha i v \varepsilon \sigma \theta \alpha$ and

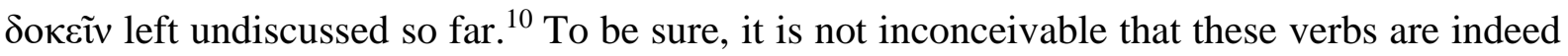
used interchangeably here, and at first sight there even seem to be good reasons to think so: just

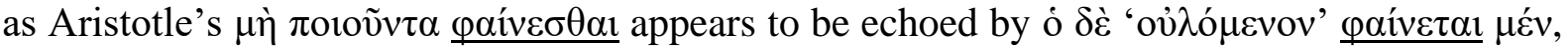

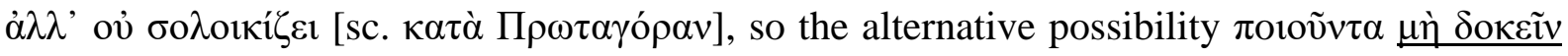

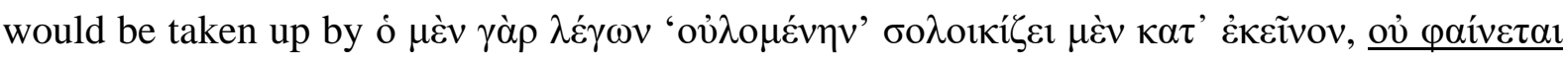

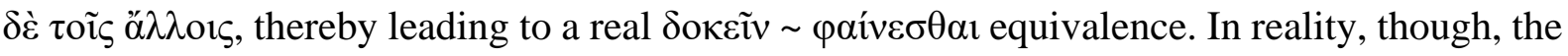

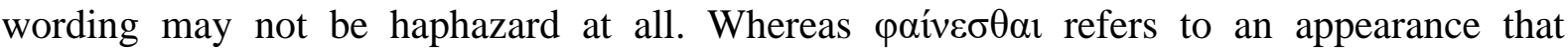
(intuitively) 'meets the eye', without a reflective process being involved, the same need not be true of $\delta$ oкعiv, which typically presupposes a stage in which the opinion or 'belief' in question ( $\delta \delta^{\prime} \xi \alpha$ ) is mentally formed. This being so, it may well be that Aristotle's reference to Protagoras

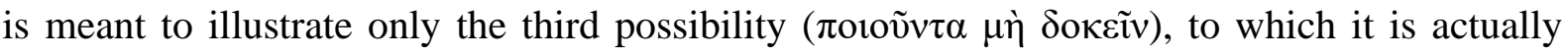

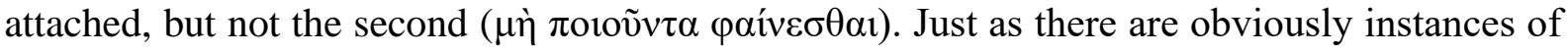

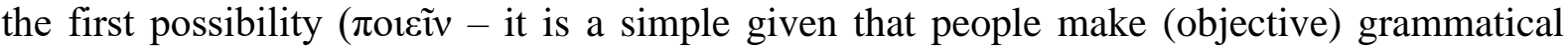
mistakes from time to time), so it can be taken for granted that there are also situations where people intuitively object to some linguistic usage, although in reality (i.e., in the eyes of someone with the appropriate grammatical training) there is no reason for doing so - in other

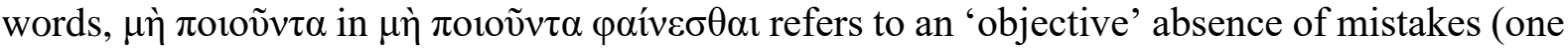
with which Aristotle would agree), not to a subjective/sophistic absence of mistakes as in

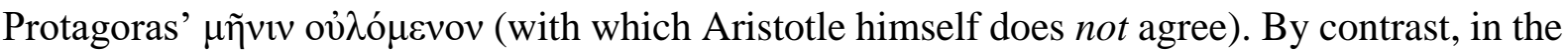
case of the third possibility Aristotle focuses on exactly the kind of situation for which

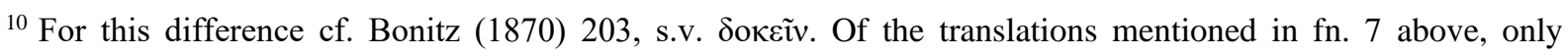
Hecquet's pays attention to it.
} 
Protagoras' wild doctrine can serve as a prime example, a situation where there is 'objectively' a mistake ( $\pi$ oเoṽv $\tau \alpha)$ but where a sophistic argumentative process nevertheless leads to the $\delta$ ó $\xi \alpha$

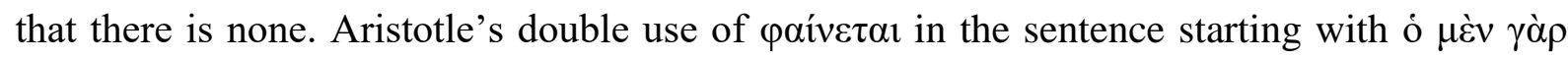

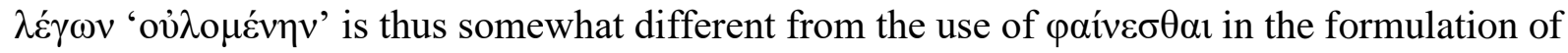

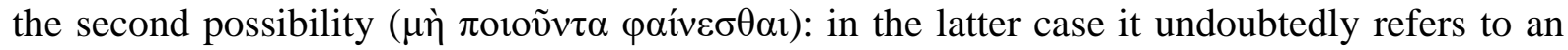
(according to Aristotle) erroneous view, whereas in the former case it refers to a view that is shared by Aristotle as one of the ö $\lambda \lambda$ or (since opposed to Protagoras' odd idea) and hence

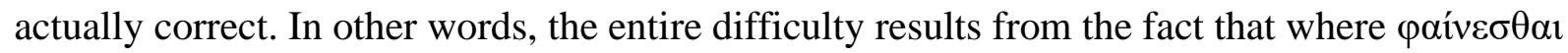
is first used it contrasts with an unqualified 'objective' truth, and therefore must be understood as entailing a 'mere appearance', whereas where it is subsequently used it contrasts with another opinion - that of Protagoras -, without the entailment that the 'appearance' is a 'mere appearance' (except of course from Protagoras' point of view).

\subsection{Protagoras' reasoning}

Moving on, the fundamental question is of course how Protagoras actually argued his case. It is here that the real controversy begins, since Aristotle does not explain Protagoras' reasoning in any detail. Perhaps prompted by Aristotle's own interest in mismatches between grammatical gender and biological sex, ${ }^{11}$ some scholars, including Murray, Most, Sluiter and Di Cesare, claim that Protagoras' point was purely semantic and took into account the supposedly 'masculine' nature of $\mu \tilde{\eta} v i \varsigma$ as an emotion and of $\pi \eta \dot{\lambda} \eta \xi$ as a piece of warfare equipment. ${ }^{12}$

\footnotetext{
${ }^{11}$ Cf. SE 166b10-12, quoted in Section 2.6; Schreiber (2003) 46-7.

${ }^{12}$ See Murray (1946) 177 ('[Protagoras] seems also to have argued that words of such unfeminine character as $\pi \hat{\eta} \lambda \eta \xi$, helmet, and $\mu \tilde{\eta} v i \varsigma$, wrath, might be made masculine'); Most (1986) 68-9 ('il est impossible que la passion

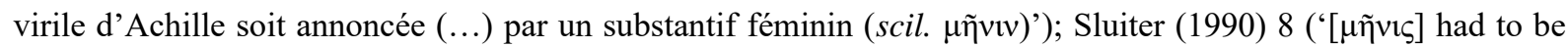
masculine, probably on the ground that $\mu \tilde{v} v 1 \varsigma$ is a male passion'); Di Cesare (1991) 102: 'Protagoras [schlägt] das
} 
Others, however, argue that more formal considerations may have played a role. Thus, Gomperz, echoed by Wackernagel and Fehling, ${ }^{13}$ suggests that $\pi \eta \dot{\lambda} \eta \xi$, at least, may have been classified as masculine by Protagoras on analogy of other masculine nouns in $-\alpha \xi$ (ó $\theta \omega ́ \rho \alpha \xi$, $\dot{0}$ $\pi$ ó $\rho \pi \xi \xi$, $\delta \tau \dot{v} \rho \alpha \xi)$, though they maintain that $\mu \tilde{\eta} v i \varsigma$ was designated masculine because of its meaning only, since nouns in $-1 \varsigma$ are generally feminine. ${ }^{14}$ Yet others, including Guthrie and Corradi, suggest that formal distinctions may in fact have been paramount for Protagoras, arguing that what matters is that both $\mu \tilde{\eta} v i \varsigma$ and $\pi \hat{\eta} \lambda \eta \xi$ end in $-s .{ }^{15}$ Finally, there are those who

männliche Geschlecht (...) vor, (...) weil dieses Genus für die Eigenschaften des Zorns und des Helms Eigenschaften, die für "objektiv" männlich gehalten werden - angemessener zu sein scheint'); cf. also Siebenborn (1976) 15, Schreiber (2003) 47, 50, Graham (2010) 2.721 (with his translation cited in fn. 7 above). The alleged

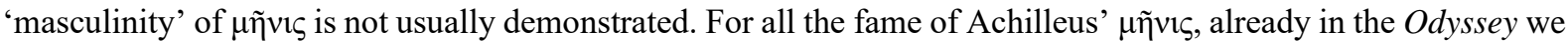

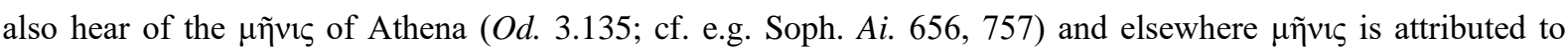
Demeter (h.Cer. 350), Hera (Aesch. Supp. 163) or the Furies (Aesch. Eum. 314, 889), among others. Personified Mñvic is of course feminine as well (Aesch. Ag. 155, 702).

${ }^{13}$ Gomperz (1922) 369, Wackernagel (1928) 4-5, Fehling (1965) 215. There are, however, telling divergences in the detail: whereas Gomperz (1922) 368 found that '[d]ie Endung -x ist in der Regel ein Kennzeichen weiblichen Geschlechts, aber keineswegs ausnahmslos', the exceptions precisely being 'drei Worte, die je einen Bestandteil der Kriegsrüstung bezeichnen', Wackernagel (1928) 4, who seems unsure of the formal approach anyway, (questionably) claimed that 'die meisten Substantiva auf $\xi$ sind Maskulina'. Fehling (1965) 215 then suggested ‘daß Protagoras geschickt von $\mu \eta \tilde{v} v \varsigma$ zu $\pi \eta ́ \lambda \eta \xi$ ausgewichen ist, wo er eine plausible Analogie hatte’.

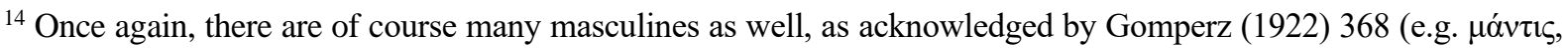

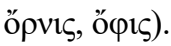

${ }^{15}$ Guthrie (1971) 221-2 n. 1, Corradi (2012) 152-3. However, Corradi later paraphrases Protagoras' thought as 'Omero avrebbe dovuto concordare questo nome [sc. $\mu \tilde{\eta} v ı \varsigma$ ] con ov̉ $\lambda$ ó $\mu \varepsilon v o \varsigma$ attribuendogli il genere maschile, proprio della desinenza e soprattutto più adatto a mettere in evidenza la natura virile del sentimento dell'eroe' (Corradi (2012) 164, italics added). 
leave the matter open, including Kerferd, Dorion, Rademaker, Hecquet and Novokhatko, suggesting that both types of reasoning may have played a role. ${ }^{16}$

In our view, the third group of scholars is correct and Protagoras' argument did indeed have to do with 'morphological' consistency (in scare quotes, because, as will become clear, Protagoras did not have the concept of a morpheme, but looked at the final letters of words). One key piece of evidence concerns a strange chapter in Aristotle's Poetics:

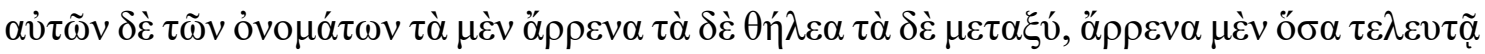

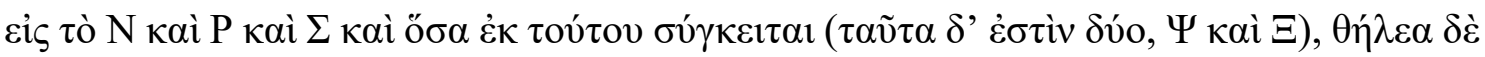

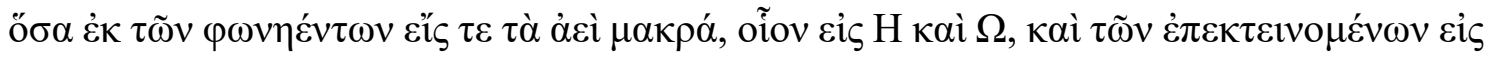
A·

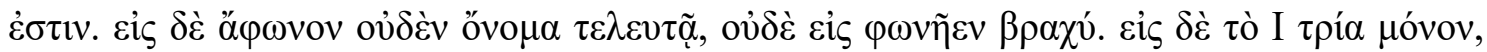

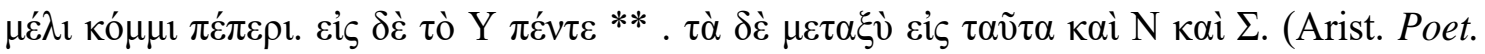
$1458 \mathrm{a} 8-17)$

Of the nouns themselves, some are masculine, some feminine and some neuter. Masculine are all that end in $-\mathrm{N}$ and $-\mathrm{P}$ and $-\Sigma$ and all that end in a compound of $\Sigma$ (there are two of these, $\Psi$ and $\Xi)$. Feminine are all that end in the vowels which are always long, that is $-\mathrm{H}$ and $-\Omega$, and those that end, from among the vowels that can be lengthened, in -A. The result is that the number of masculine and feminine terminations is the same; for $\Psi$ and $\Xi$ are compounds. No noun ends in a mute consonant or in a short vowel [i.e. a

\footnotetext{
${ }^{16}$ Kerferd (1981) 69, Dorion (1995) 312-13, Rademaker (2013) 90, Hecquet (2019) 221 n. 5, Novokhatko (2020) 108. Rademaker's translation of the relevant clause by 'if mênis and pêlêx are masculine things' favours the semantic approach, while Hecquet’s rendering of ö $\rho \rho \varepsilon v \alpha$ as ‘du genre masculin’ favours the formal one.
} 


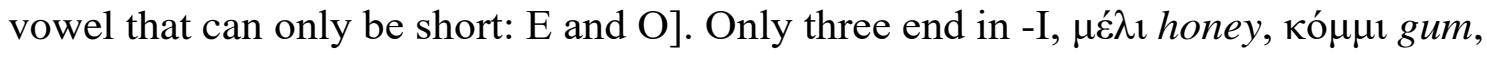
and $\pi \varepsilon \dot{\pi \varepsilon \rho 1 ~ p e p p e r . ~ F i v e ~ e n d ~ i n ~}-\mathrm{Y}, * *$. The neuters end in these and in $-\mathrm{N}$ and $-\Sigma$.

This chapter sits oddly in the Poetics and has been thought to be an interpolation, ${ }^{17}$ although it does use the Aristotelian term for 'neuter', $\mu \varepsilon \tau \alpha \xi$; ; given the evidence of $S E$, Protagoras would

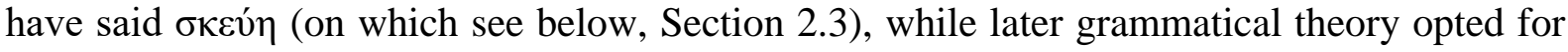

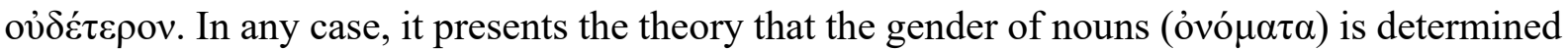
by their final letter: words ending in $-\mathrm{N},-\mathrm{P},-\Sigma,-\Psi$ and $-\Xi$ are masculine, those ending in $-\mathrm{H}$ and $-\Omega$ and long and short $-\mathrm{A}$ are feminine, and words that end in $-\mathrm{I}$ and $-\mathrm{Y}$ are neuter, as are some words that end in $-\mathrm{N}$ and $-\Sigma$. (Some editors at the suggestion of Bywater read the final

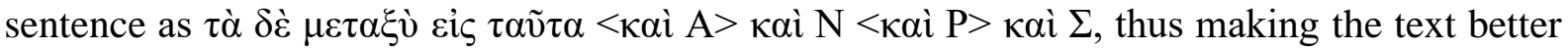
fit our own grammatical knowledge; the addition of A also helps explain the term $\mu \varepsilon \tau \alpha \xi v$ : the neuter partakes of the terminations of both other categories.)

The main reason to connect this passage to a doctrine of Protagoras is that it neatly fits with what we know the sophist said about the gender of $\mu \tilde{\eta} v i \varsigma$ and $\pi \dot{\eta} \lambda \eta \xi$, and that it also ties in with the parody of (what everyone has always assumed are Protagoras') ideas on gender in Aristophanes' Clouds 658-93 (cf. Section 2.5). Moreover, since the doctrine put forward is so patently wrong from a descriptive point of view, it is best understood as originating from a prescriptive perspective, and that would seem to be much more in line with Protagoras' evident wish to baffle his audience than with sober Aristotelian scholarship. ${ }^{18}$ But we can go further than that and make two additional points.

First, despite (or because of) its wrong-headedness, which culminates in internal contradiction - if 'masculine are all [nouns] (ö $\sigma \alpha)$ that end in $-\mathrm{N}$ and $-\mathrm{P}$ and $-\Sigma$ ', there cannot

\footnotetext{
${ }^{17}$ See Corradi (2012) 153 for bibliography.

${ }^{18}$ Cf. Dorion (1995) 313, Hecquet (2019) 221 n. 5.
} 
logically be another category of nouns equally ending in $-\mathrm{N}$ and $-\Sigma$, as stipulated at the end - , the list is highly instructive. There is one category of nouns for which the terminations of

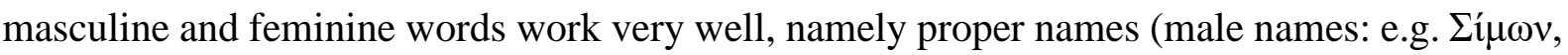

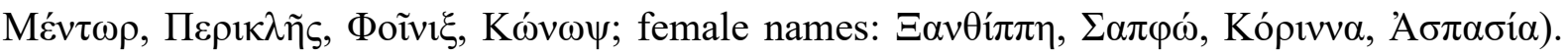
We would now argue that proper names are exactly the right place to start for a linguist who for the first time attempts to show that certain grammatical distinctions in a language are related to the concept of 'gender' (and not, say, 'size' or whatever). They offer a natural bridge between form and meaning, as is neatly highlighted by the parodic scene in Clouds where personal names do indeed play a central role (though of course also because they can serve as a cue to ridicule specific individuals: Ar. Nub. 680-93). Protagoras' reasoning may thus have been as follows: you take the personal names and show that they quite consistently terminate in certain letters when they are names for men, and in other letters when they are names for women. ${ }^{19}$ You then generalize the formal criterion to all nouns, including $\mu \tilde{\eta} v i \varsigma$ and $\pi \dot{\eta} \lambda \eta \xi .{ }^{20}$ As for the

\footnotetext{
${ }^{19}$ In contrast to the situation among common nouns, where large categories like the feminines in $-\sigma 1 \zeta$ have to be

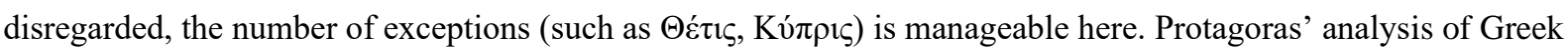
names may also have inspired Herodotus' comparable, though factually more problematic, claims about Persian

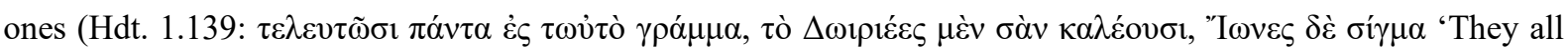
end in the same letter, which the Dorians call "san", the Ionians "sigma").

${ }^{20}$ In this context the bold interpretation of the passage from $S E$ by Lougovaya and Ast (2004) deserves mention.

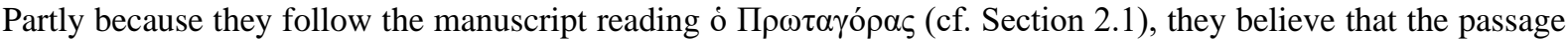
'does not state that Protagoras believed that the person who employs the definite article $\dot{\eta}$ with $\mu \tilde{\eta} v 1 \varsigma$ commits a solecism' (Lougovaya and Ast (2004) 275). They suggest instead that Protagoras had in mind the personal name

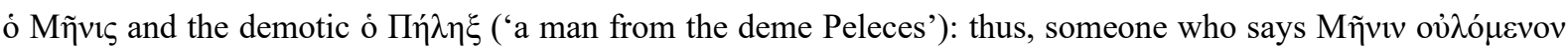
seems to commit a solecism (because everyone thinks of Iliad 1.1-2 and the word $\dot{\eta} \mu \tilde{\eta} v ı$ ), but does not in fact do

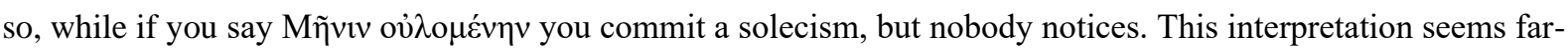

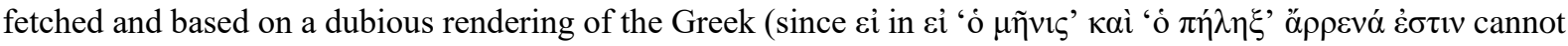
mean 'in the case where' = ö $\tau \alpha v /$ ó ótav). Moreover, it lacks applicability beyond the two exceedingly rare
} 
neuter, Protagoras may have started by enumerating the (limited number of) words that terminate in the remaining letters in which Greek words may end, namely -I and -Y, and concluded that they all refer to 'things' ${ }^{21}$ (We will return below to neuter words ending in -N and $-\Sigma$.) Such a transfer from names to nouns more generally was no doubt aided by the fact that the term övo $\mu \alpha$ could refer to either of the two groups of words - so that, as long as the 'right' meaning of övo $\mu \alpha$ is picked, even the claims that 'all the (ö $\sigma \alpha)$ óvó $\mu \alpha \tau \alpha[=$ "proper names"] in $-\mathrm{N},-\mathrm{P},-\Sigma$ are masculine' and 'the neuter óvó $\mu \alpha \tau \alpha$ [= "nouns"] end in $-\mathrm{I},-\mathrm{Y},-\mathrm{N},-\Sigma$ ' are no longer contradictory. ${ }^{22}$

Secondly, it may be significant that the issue of nouns ending in $-\Xi$ and $-\Psi$ is of some relevance to the argument of the Poetics passage, for the balance in number between masculine and feminine nouns/names only works as long as the items in $-\Xi$ and $-\Psi$ are treated as a subcategory of those in $-\Sigma$. That in itself is a perfectly reasonable view, which could originate with Aristotle just as easily as with Protagoras. ${ }^{23}$ But only if the entire doctrine ultimately went back to the latter, could we finally also make out why Protagoras, in addition to $\mu \tilde{\eta} v 1 \varsigma$, chose $\pi \eta \dot{\lambda} \eta \xi$ to illustrate his point. Being the first word of the Iliad, feminine $\mu \tilde{\eta} v ı \varsigma$ was of course a godsend to capture everyone's attention; but if the whole point was to strike the audience with

onomastic items it would involve, of which Mñvı $\varsigma$ is not even securely attested before the third century BC (cf. Corradi (2012) 150 n. 2).

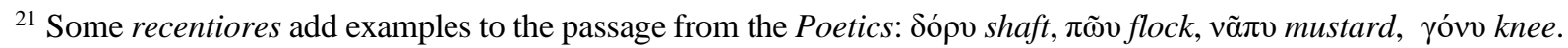
Herodian (I p. 354-5 Lentz) lists about twenty words in - 1 and ten in -v.

${ }^{22}$ The ambiguity was finally resolved when the Stoics separated out the ỏvó $\mu \alpha \tau \alpha \pi \rho \circ \sigma \eta \gamma o \rho ı \kappa ́$ (or $\pi \rho \circ \sigma \eta \gamma o \rho i ́ \alpha$ )

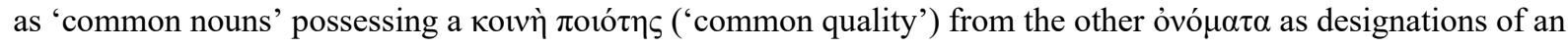

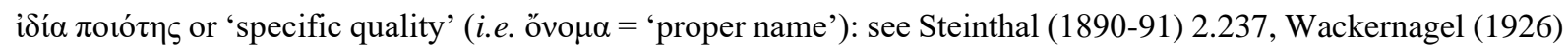
14.

${ }^{23}$ Hailing from the Ionian colony Abdera, Protagoras himself will have been used to the letters $\Xi$ and $\Psi$ already in the fifth century, just as Aristotle certainly was in the fourth; but Protagoras' Athenian audience was still employing the digraphs $\mathrm{X} \Sigma$ and $\Phi \Sigma$ at the time. 
'wrong' feminines, why go for $\pi \eta \dot{\lambda} \lambda \eta \xi$ next, rather than a high-frequency word such as $\pi$ ó $\lambda$ เ or

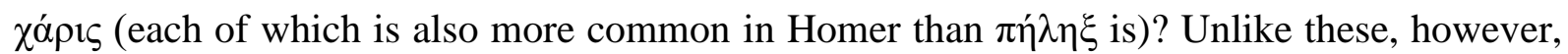
$\pi \eta \dot{\lambda} \eta \xi$ was the ideal example if there was at the same time a need to come up with an item ending in one of the 'compound letters'; for of all the Homeric nouns in $-\xi$ or $-\psi, \pi \eta \dot{\eta} \lambda \eta \xi$ with its ten attestations (of which several with an unambiguously feminine attribute: e.g. Il. 13.527

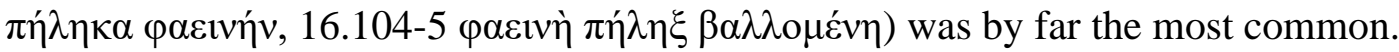

\subsection{Protagoras' terminology}

There are several additional considerations which make it plausible that Protagoras' argument was in the first place a formal one, and some of them offer tantalizing further possibilities to follow his reasoning. The first concerns Protagoras' terminology and is very simple; yet, it has

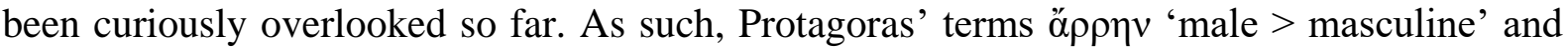
$\theta \tilde{\eta} \lambda v \varsigma_{\varsigma}$ 'female $>$ feminine' seem straightforward enough, both because of the likely role played by male and female names in the development of the theory (Section 2.2) and also, more generally, because at least the most prototypical members of the respective declension classes do designate male and female beings, respectively (e.g. $\alpha v \eta ́ \rho / \gamma v v \eta ́, ~ \delta \varepsilon \sigma \pi o ́ \tau \eta \varsigma / \delta \varepsilon ́ \sigma \pi o เ v \alpha$, etc.).

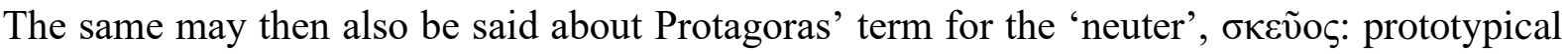

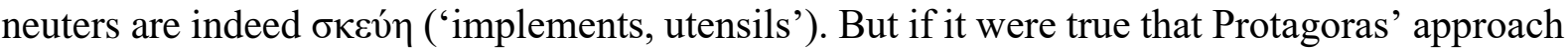
had been a semantic one, this would lead to a glaring paradox. Whatever one may think about emotions, and their possible associations with men or women (cf. $\mu \tilde{\eta} v \imath \varsigma)$, Protagoras' argument about $\pi \eta \dot{\lambda} \lambda \eta \xi$ simply could no longer stand: since the noun $\sigma \kappa \varepsilon \tilde{v} о \varsigma$ often specifically refers to pieces of equipment, including military gear, ${ }^{24}$ it would have been nothing but perverse for Protagoras to object to the current classification of $\pi \dot{\eta} \lambda \eta \xi$ among the $\theta \dot{\eta} \lambda \varepsilon \alpha$, only to then place

\footnotetext{
${ }^{24}$ Cf. LSJ 1607, s.v., referring to Thuc. 6.31 and Xen. Cyr. 4.5.55.
} 
that word among the ö $\rho \rho \varepsilon v \alpha$ and not among the $\sigma \kappa \varepsilon v ́ \eta$ where it so evidently belonged if the meaning was anything to go by. In other words, the basis for claiming that $\pi \hat{\eta} \lambda \eta \xi$ is really masculine rather than feminine must have been unrelated to semantics.

\subsection{The continuation of Sophistici Elenchi}

Next, immediately following the passage from Aristotle's Sophistici Elenchi found in editions of the fragments of Protagoras, there is a further discussion of 'seeming solecisms' involving both gender and inflection $(\pi \tau \tilde{\omega} \sigma 1 \varsigma)$ (173b26-174a9). The sophistic line of reasoning which Aristotle dissects relies on the fact that neuter words have the same form in the nominative and accusative, whereas masculine and feminine words do not. Thus, in both 'it is a log (है $\sigma \tau 1$

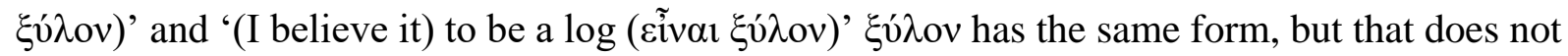

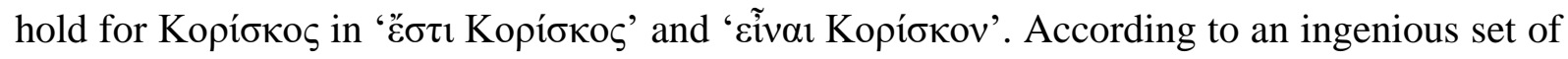
questions which Aristotle spells out only later (182a10-182b2) this discrepancy allows sophists to pretend that an interlocutor saying (accusative) Kopíбкov is in fact claiming that it should be

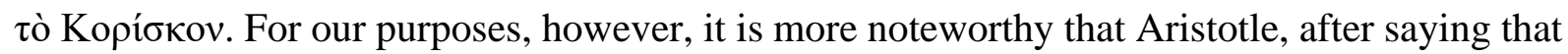

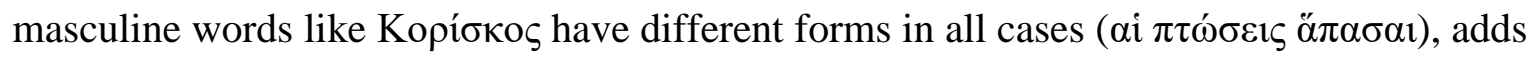

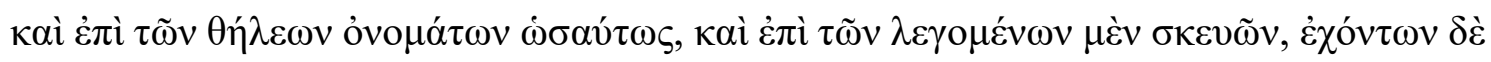

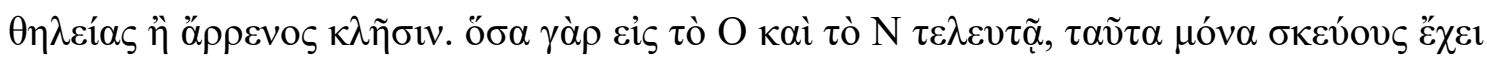

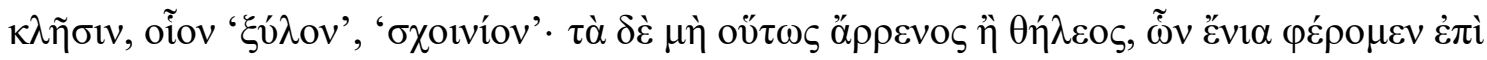

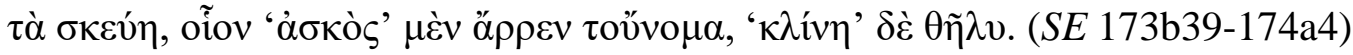

it is the same with feminine nouns and with the words that are called 'things' but have a feminine or masculine designation. For only those that end in -O- plus - $\mathrm{N}$ have the

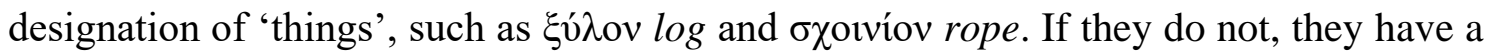


masculine or feminine one, and some of these we apply to 'things', such as the masculine noun $\dot{\alpha} \sigma \kappa o ́ \varsigma$ wine-skin and the feminine noun $\kappa \lambda i ́ v \eta ~ b e d$.

So far we have only come across evidence to suggest that Protagoras limited his speculations about the connections between grammatical form and gender to the final letters of words (Section 2.2). However, in connection with the transfer from names to nouns we have also already seen that, while the 'rule' he postulated served his purpose in some respects, it has various shortcomings. Of course, Protagoras was not a descriptive linguist, but rather used his 'rule' to make prescriptive pronouncements. ${ }^{25}$ But even within such a framework, there are limits to what one can get away with. The most glaring problem concerns the neuter. After all, there are really very many neuter words ending in $-(0) v$ and also many in $-(0) \zeta$, which according to Protagoras' 'rule' should all be masculine. It is therefore interesting to note that in this passage of $S E$ Aristotle takes up the point of neuter terminations and uses the word Protagoras

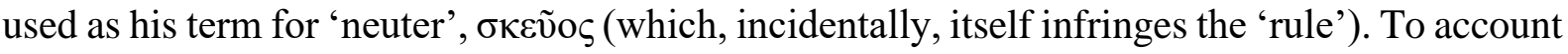
for this, we would tentatively suggest that the passage is based on an elaboration of Protagoras' theory, moving from a consideration of the final letter of words to a consideration of the final two letters; and it is at least conceivable that already Protagoras himself had found himself forced to make this concession and refine his claims.

\subsection{The parody in Aristophanes' Clouds}

\footnotetext{
${ }^{25}$ Not necessarily in the sense that he would have promoted real linguistic reform, or 'adjusted' his own usage (as suggested by Lana (1950) 56-9; cf. also Siebenborn (1976) 16, Kraus (1987) 190), but certainly by finding fault with Homer.
} 
Furthermore, in the passage just cited Aristotle shifts the focus away from a consideration of the nominative form alone, in order to expose the trap used by the sophistic $\varepsilon^{\prime} \lambda \varepsilon \gamma \chi 0 \varsigma$. Instead, he suggests, attention may profitably be paid to the declension pattern as a whole, involving

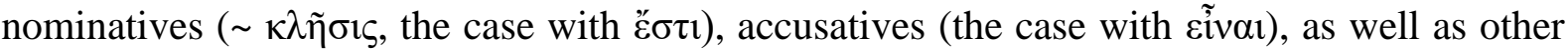

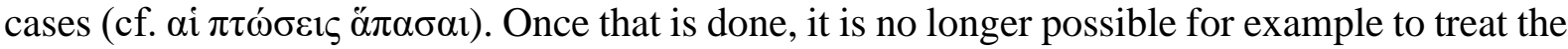

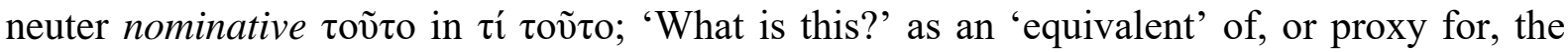
masculine accusative $\tau$ oṽ $\tau$ ov - as the sophists whom he rebukes appear to have done in order to confuse their interlocutors. No one is specifically named here, but in view of the preceding discussion of Protagorean sophistry, it would not surprise if Protagoras had also been guilty of such kinds of trickery.

This suspicion becomes even stronger once we realise that Aristophanes staged a surprisingly similar kind of sophistic trap in the grammar scene of Clouds whose Protagorean inspiration is generally acknowledged. We will first discuss this similarity, before showing that the exchange leading up to it also has 'Socrates' operating like a grammarian whose interest in the form of words trumps semantic considerations (Ar. Nub. 681-93):

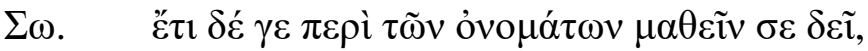

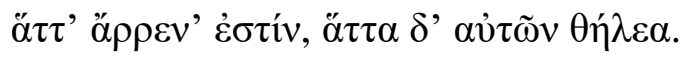

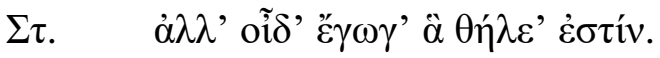

$\Sigma \omega$.

$\Sigma \tau . \quad \quad \quad \Lambda v ́ \sigma \imath \lambda \lambda \alpha, \Phi i ́ \lambda \imath v v \alpha, \mathrm{K} \lambda \varepsilon \imath \tau \alpha \gamma o ́ \rho \alpha, \Delta \eta \mu \eta \tau \rho i ́ \alpha$.

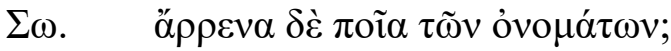

$\Sigma \tau$

$\mu v \rho i ́ \alpha$.

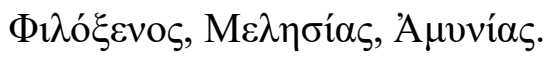




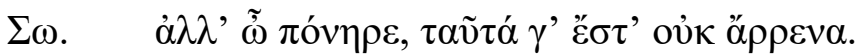

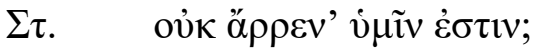

$\Sigma \omega$.

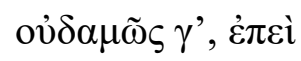

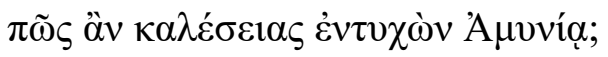

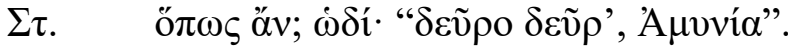

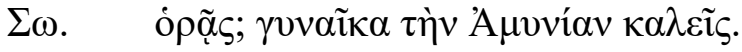




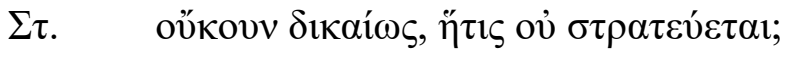

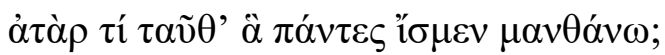

SO. Also, you have to learn which names are male and which are female.

ST. But I know which ones are female!

SO. Go ahead then.

ST. Lysilla, Philinna, Kleitagora, Dêmêtria.

SO. And which names are male?

ST. An awful lot: Philoxenos, Melêsias, Amynias...

SO. Silly you, these are not male!

ST. They are not male according to you?

SO. No, not at all: how would you call Amynias when you see him?

ST. How? Like this: "Hello, hello, Amynia!"

SO. You see? You are calling a woman, "Amynia"!26

ST. Isn't that right, given that she doesn't do military service? Why do I have to learn these things we all know anyway?

Although he is eventually outwitted by Strepsiades' simple mind, 'Socrates' here seeks to trip up his pupil in exactly the way Aristotle's discussion suggests: by glossing over the fact that nouns/names are grammatically defined by their declension pattern, and that the formal identity of one case form to another case form (in Aristotle, the neuter nominative $\tau$ oṽ $\tau$ and the neuter

\footnotetext{
${ }^{26}$ This is how the line is best translated, since 'You are calling Amynias a woman' does not fit what Strepsiades

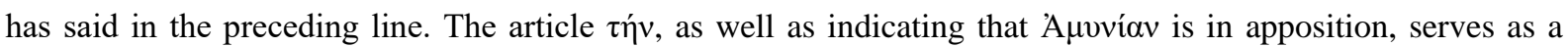

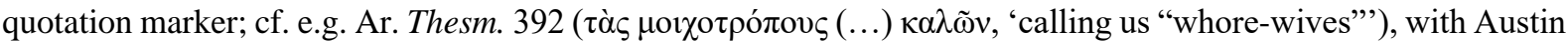
and Olson (2004) ad loc.
} 
accusative $\tau$ oṽ $\tau$; in Aristophanes, the masculine vocative in $-\alpha$ and the feminine nominative in $-\alpha)$ does not of its own warrant any conclusion about the function which the form in question has.

Importantly, meanwhile, 'Socrates"' argumentation is an exclusively formal one both in this case and throughout the scene. It is therefore misleading to suggest that the Aristophanic passage lends support to the idea that Protagoras' classification criteria, when dealing with $\mu \tilde{\eta} v i \varsigma$ and $\pi \dot{\eta} \lambda \eta \xi$, may have been a semantic as well as a formal one. ${ }^{27}$ Of course Aristophanes' primary aim is to make his audience laugh, not to give a glimpse into a real sophist's classroom. Even so it is telling that the only stage character who takes semantics as the baseline when asked to think about grammatical gender is the uneducated Strepsiades. It is he who ultimately 'justifies' the seemingly feminine form of address 'A $\mu v v i$ a by reference to the historical Amynias' effeminate character. 'Socrates', by contrast, does not argue along the lines of 'Amynias is effeminate, hence his name must be feminine' (as would be implied by the allegedly Protagorean argument that ' $\mu \tilde{\eta} v i \varsigma$ is a male feeling, hence its name must be masculine').

The same is true in the other two sections of the Aristophanic scene. As already remarked, the first deals with zoonyms (Ar. Nub. 658-69):

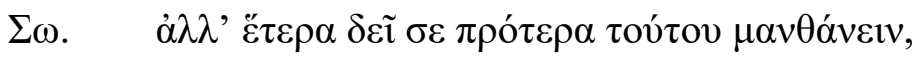

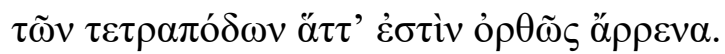

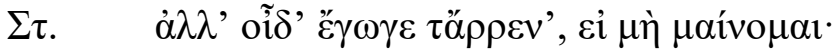

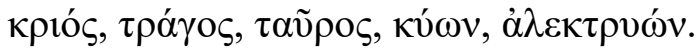

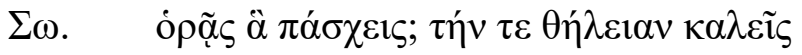

\footnotetext{
${ }^{27}$ Thus Kerferd (1981) 69 ('Both criteria, that of morphological consistency, and that of consistency with natural gender, are found in the satirical passage in Aristophanes' Clouds'); Corradi (2012) 154.
} 


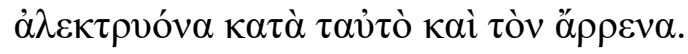

$\Sigma \tau . \quad \pi \tilde{\omega} \varsigma \delta \eta ́, \varphi \varepsilon ́ \rho \varepsilon$

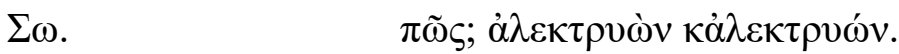

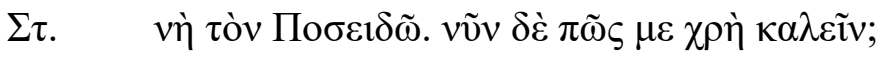

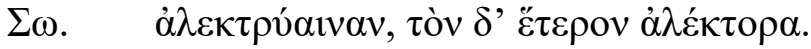

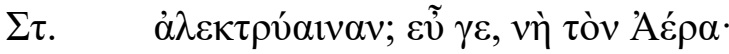

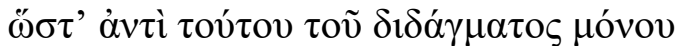

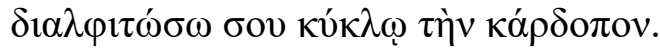

SO. But before that you have to learn other things, which of the four-footed beings are truly male.

ST. But I know the male ones, unless I'm mad: ram, he-goat, bull, dog, cock (alektryôn).

SO. See what's happening to you? You call the female alektryôn just like the male.

ST. How that, come on?

SO. How? Well, alektryôn and alektryôn!

ST. By Poseidon, and how am I supposed to call it now?

SO. alektryaina, and the other one alektôr.

ST. alektryaina? That's a good one, by Air! For that piece of instruction alone I will fill your kneading-trough with meal, all around!

Once again, Socrates does not proceed by saying 'A hen is female, so the word we normally use for hen ( $\dot{\alpha} \lambda \varepsilon \kappa \tau \rho v \omega ́ v)$ must also be treated as grammatically feminine'. In fact, that is precisely what he objects to: $\dot{\alpha} \lambda \varepsilon \kappa \tau \rho v \omega ́ v$ cannot be grammatically feminine because its form 
(ending in $-(\omega) v$, rather than e.g. $-(\alpha v) \alpha)$ is such that it is incompatible with femininity. ${ }^{28}$ And

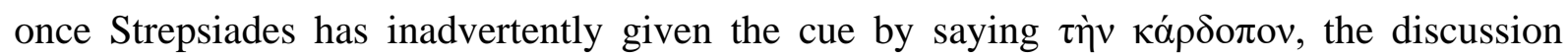
continues accordingly (Ar. Nub. 670-80):

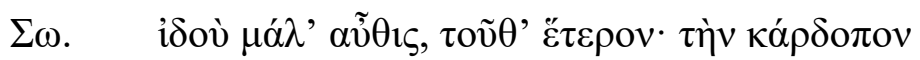

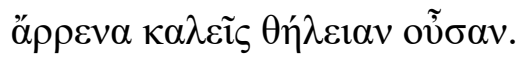

$\Sigma \tau$ $\tau \tilde{\varphi} \tau \rho o ́ \pi \omega$

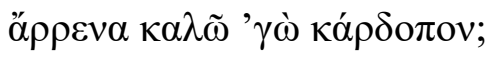

$\Sigma \omega$.

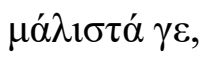

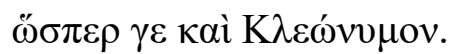

$\Sigma \tau$ $\pi \tilde{\omega} \zeta \delta \eta \dot{\eta} ; \varphi \rho \alpha ́ \sigma o v$.

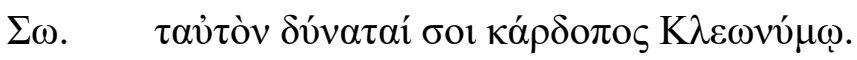

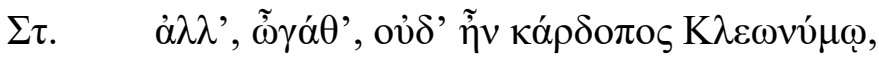

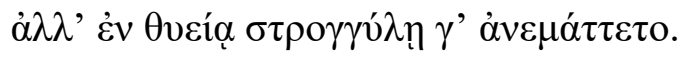

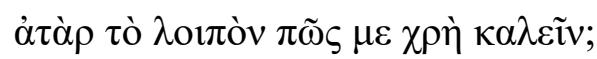

$\Sigma \omega$. Ő $\pi \omega \varsigma ;$

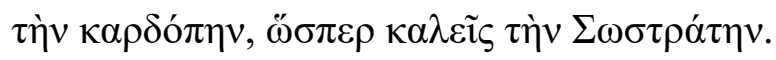

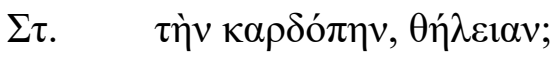

$\Sigma \omega$.

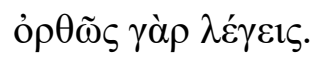

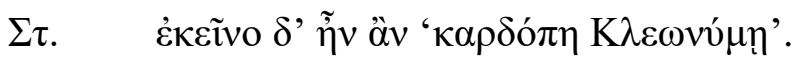

\footnotetext{
${ }^{28}$ Wackernagel (1928) 2 stresses that the standard feminine counterpart of $\dot{\alpha} \lambda \dot{\varepsilon} \kappa \tau \omega \rho$ would be $\dot{\alpha} \lambda \varepsilon \kappa \tau o \rho i ́ \zeta$, whereas $\dot{\alpha} \lambda \varepsilon \kappa \tau \rho v ́ \alpha \iota v \alpha$ is an Aristophanic invention. However, since $\dot{\alpha} \lambda \varepsilon \kappa \tau \rho v ́ \alpha \iota v \alpha$ next to $\dot{\alpha} \lambda \varepsilon \kappa \tau \rho v \omega ́ v$ is regular from a strictly formal point of view (cf. $\delta \rho \alpha ́ \kappa \omega v / \delta \rho \alpha ́ \kappa \alpha \iota v \alpha)$ ), it is more remarkable that 'Socrates', having replaced feminine $\dot{\alpha} \lambda \varepsilon \kappa \tau \rho v \omega ́ v$, also wants to get rid of masculine $\dot{\alpha} \lambda \varepsilon \kappa \tau \rho v \omega ́ v$. This is probably not because (ó) $\dot{\alpha} \lambda \varepsilon \kappa \tau \rho v \omega ́ v$ would have been an epicene noun (as Janse (2020) 28 seems to suggest; but cf. Ar. fr. 17 and Pl. Com. fr. 293 with $\dot{\eta} \dot{\alpha} \lambda \varepsilon \kappa \tau \rho v \omega ́ v$ and $\tau \grave{\alpha} \varsigma \dot{\alpha} \lambda \varepsilon \kappa \tau \rho v o ́ v \alpha \varsigma)$ but because $\dot{\alpha} \lambda \varepsilon \dot{\varepsilon} \kappa \tau \omega \rho$ sounded more unambiguously masculine.
} 
SO. Again, see? another example: you call the kneading-trough (kardopos) a male although it is female.

ST. In what way? I call a kneading-trough male?

SO. Yes, indeed, just like Kleonymos.

ST. How do you mean, tell me.

SO. For you a kneading-trough is the equivalent of Kleonymos.

ST. But, mate, Kleyonymos didn't have a kneading-trough - he kneaded in a round mortar. So what do I have to say in the future?

SO. What you have to say? Well, kardopê, just as you say Sôstratê.

ST. Female kardopê?

SO. Yes, correct.

ST. So it would be 'a kardopê for Kleônymê'!

In this case we get yet another variation on the same theme. The feminine gender of the word for 'kneading-trough' is established, not on the basis of a supposed association of the implement with women - in the same way as the association of a $\pi \dot{\eta} \lambda \eta \xi$ with men has been alleged to work -, but on the basis of the formal characteristic of the $\kappa \alpha \rho \delta$ o $\pi$ - lexeme taking a feminine article; so agreement is brought in, just as it was by the real Protagoras in his discussion of the

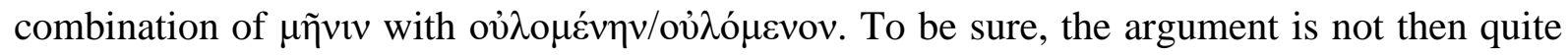

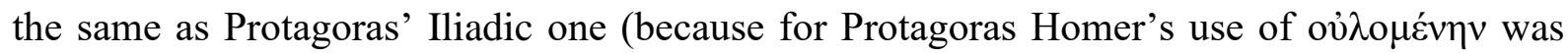
clearly not a reason to regard $\mu \tilde{\eta} v ı \varsigma$ as feminine, let alone turn it into something like * $\mu \eta v i ́ \eta)$, but the essential point is still that semantic considerations are lacking. ${ }^{29}$ Had these been of any

\footnotetext{
${ }^{29}$ Cf. Janse (2020) 29-30: 'The point of Socrates' digression is that nouns belonging to the second declension should be masculine and those belonging to the first declension feminine - whether naturally (
} 
importance to Protagoras' doctrine about gender, it would have been easy enough for the comic poet to capitalize on them. Their absence from Clouds therefore reinforces the impression that Protagoras' focus must have been a formal one.

\subsection{The introduction of Sophistici Elenchi}

Finally, we must beware that collections of fragments are treacherous things: they make scholars ignore the wider context of the text from which they have been taken, even though that context may be highly relevant to the interpretation of the fragment. This is the case with the passage from the Sophistici Elenchi as well. Any remaining doubt that Protagoras used a formal argument to argue that $\mu \tilde{\eta} v i \varsigma$ and $\pi \dot{\eta} \lambda \eta \xi$ are masculine is dispelled when we consider the context in which Aristotle discusses the claim.

It is especially fruitful to look at the introduction of $S E$, in which Aristotle gives a brief summary of its contents. In describing what he will do in 'our' section, he mentions fallacious

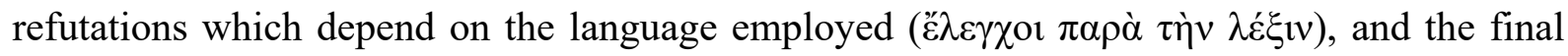
subcategory of those refutations are those that depend on 'the form of the expression':

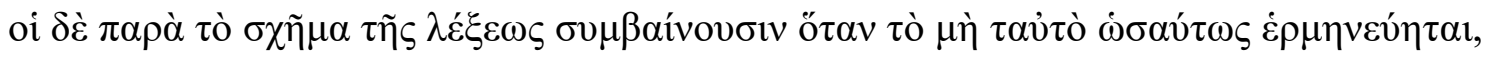

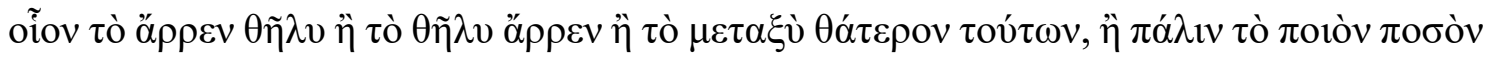

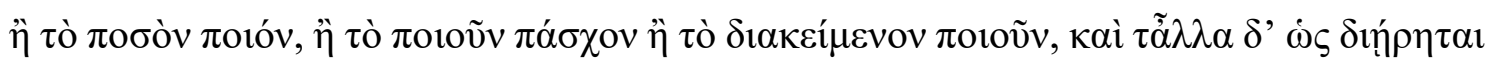

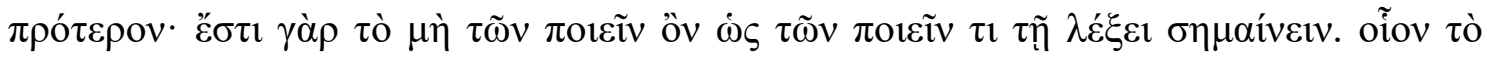

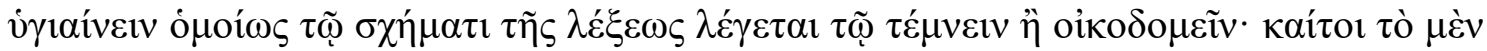

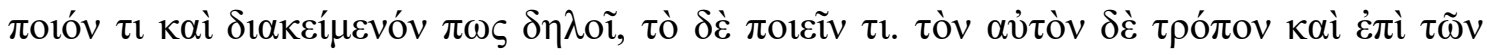
ö $\lambda \lambda \omega v$. (Arist. SE 166b10-19)

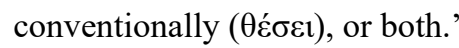


The [refutations] which depend on the form of expression occur when what is not the same is expressed in the same way. For example, when a masculine/male [item is expressed as] a feminine, a feminine/female [item] as a masculine or a neuter one as either of the other two. Or again, if a quality [is expressed as] a quantity or a quantity as a quality, or an action as a passive or a disposition as an action, and so forth according to the distinctions made earlier. For it is possible for something which does not belong to the category of 'actions' to signify by the expression used that it belongs to the category of 'actions'. For instance, 'to be healthy (íraívelv)' is expressed by means of the same

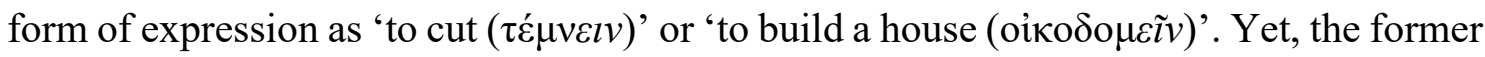
denotes some quality and disposition, the latter [two] an action. So, too, with the other examples.

The term $\sigma \chi \tilde{\eta} \mu \alpha \tau \tilde{\eta} \varsigma \lambda \hat{\varepsilon} \xi \varepsilon \omega \varsigma$ has been much debated; it does not refer to the same concept in all of Aristotle's works. ${ }^{30}$ In this context it must refer to the form of single words or, more precisely, to that part of the form of single words to which meanings such as 'masculine' or 'feminine', or 'action' or 'disposition' can, according to the argument under discussion, be attached. This is the only conclusion that can be drawn from the example which Aristotle gives:

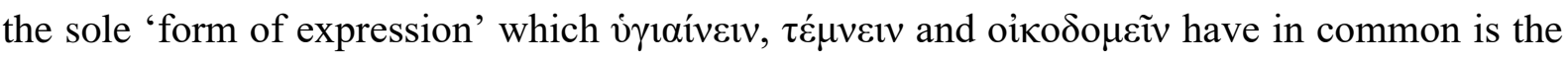
ending - $\varepsilon \imath v$. The kinds of meaning which are envisaged as being attached to a $\sigma \chi \tilde{\eta} \mu \alpha \tau \tilde{\eta} \varsigma \lambda \hat{\varepsilon} \xi \varepsilon \omega \varsigma$

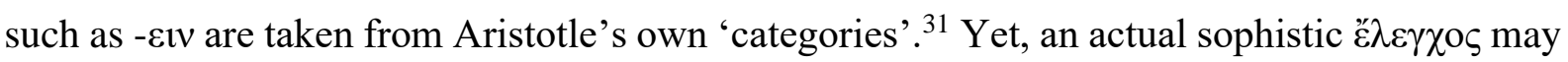

\footnotetext{
${ }^{30}$ Cf. Dorion (1995) 219-20, 230, arguing against the view that the term here may also mean 'figure of speech' and apply to entire phrases. Refutations involving more than one word come under the heading of है $\lambda \varepsilon \gamma \chi O \mathrm{\kappa} \alpha \tau \dot{\alpha}$ $\sigma u ́ v \theta \varepsilon \sigma ı v$, at least in $S E$.

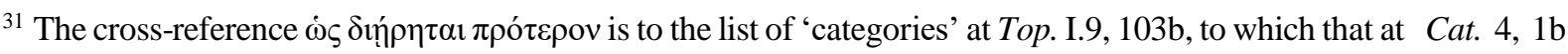

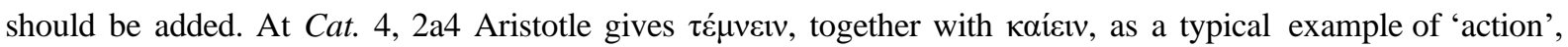


still underlie his words. The first step of such an $\varepsilon \bar{\lambda} \varepsilon \gamma \chi \circ \varsigma$ would be the sophist's observation

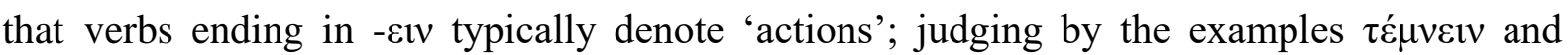

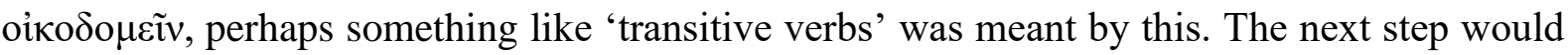
be to generalize this observation and make the interlocutor concede that -عiv means 'action'. Next, the sophist would make the unsuspecting interlocutor define the meaning of viraiveıv, which would no doubt be returned as (non-transitive) 'be healthy'; after all, that is what the verb means. The refutation which has now become possible consists in the sophist's claim that the interlocutor has wrongly defined the meaning of viraíveıv: it really means 'make healthy'. (Alternatively, and although Aristotle is not explicit about it, one can also envisage a different 'refutation': if the sophist's stipulations also included the claim that verbs ending in $-\sigma \theta \alpha \mathrm{r}$ are intransitive (the opposite of 'actions'), the refutation could consist in the claim that, in saying

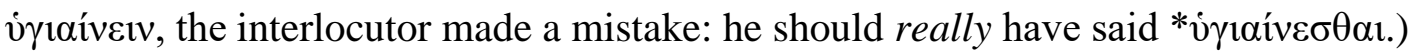

We need not assume that Protagoras himself came up with this particular "̌̉ $\lambda \varepsilon \gamma \chi 0 \varsigma$, but he does seem to have been the originator of this type of argument. One may therefore envisage a very similar reasoning to underlie the point about $\mu \tilde{\eta} v ı \varsigma / \pi \eta \dot{\lambda} \lambda \eta \xi$ being masculine.

\section{Protagoras on grammatical mood}

Diogenes Laertius credits Protagoras with a fourfold division of 'speech' ( $\lambda$ ó

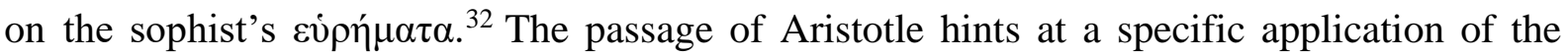

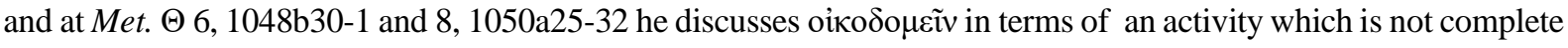
in itself. On Aristotle's classification of verbs, see Rijksbaron (1991).

${ }^{32}$ We will return to the alternative seven-fold division below. Quintilian (Inst. 3.4.10 = Radermacher B III 12) mentions Protagoras' four-fold division as well, rather strangely in the context of a discussion about alternative divisions of the main branches of rhetoric (judicial, deliberative, epideictic): Protagoran transeo, qui

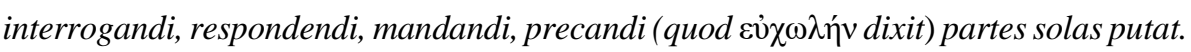


$\pi v \theta \mu \varepsilon ́ v \varepsilon \varsigma \lambda o ́ \gamma \omega v$ on the part of Protagoras. In particular, it suggests that the sophist maintained that Homer made a mistake in the first three words of the Iliad: they constitute an 'order', whereas only a 'prayer' would have been appropriate in addressing a goddess.

So, what are the $\pi v \theta \mu \varepsilon \dot{v \varepsilon \varsigma} \lambda$ ó $\gamma \omega v ?{ }^{33}$ On one interpretation, best represented by Schenkeveld (1984) 293, by using terms like 'prayer', 'question', 'answer' and 'command' Protagoras 'casually indicated ways of expressing oneself'. Accordingly, Protagoras' point concerned a sort of rudimentary idea of 'speech acts' (Rademaker (2013) 87) or the communicative value of different 'kinds of sentences' (Sluiter (1990) 7). ${ }^{34}$ On another interpretation, however, it has been pointed out that the $\pi v \theta \mu \varepsilon ́ v \varepsilon \varsigma \lambda{ }^{\prime} \gamma \omega v$ 'seem to correspond to typical uses of the four moods' (Rademaker (2013) 92), so that the terms 'prayer', 'question', 'answer' and 'command' might be be seen as 'corresponding roughly to optative, subjunctive, indicative and imperative moods of the verb, here perhaps being formally distinguished for the first time' (Graham (2010) 2.721).

Again, we think the least one can say is that the $\pi v \theta \mu \varepsilon \dot{v \varepsilon} \varsigma_{\zeta}$ ó $\gamma \omega v$ must be defined with reference to the moods. Aristotle's (non-exhaustive) list of $\sigma \chi \eta \dot{\eta} \mu \alpha \tau \alpha \lambda \varepsilon_{\varepsilon}^{\prime} \xi \varepsilon \omega \varsigma$ (here meaning something different from $S E$ ) introduces a certain amount of noise, but what we learn from him

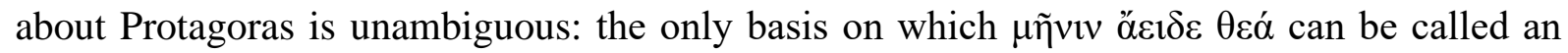
'order' is the presence of an imperative and, if so, the most obvious way in which it could be turned into a 'prayer' is by using an optative instead. Homer, so Protagoras' argument must

\footnotetext{
${ }^{33}$ Corradi (2012) 146 relates the term $\pi \nu \theta \mu \eta ́ v$ to the (Pythagorean) language of mathematics, a 'base' or 'radical', 'numero minimo dotato di una determinata proprietà', translating 'tipo fondamentale'.

${ }^{34}$ Although Guthrie ( 1971) 219-20 discusses the $\pi v \theta \mu \varepsilon ́ v \varepsilon \varsigma \lambda$ ó $\gamma \omega v$ under the heading of sophistic contributions to 'grammar', he makes no reference to grammatical mood. According to Murray (1946) 177, Protagoras' fourfold division of $\lambda$ ó $\gamma$ ○̧ shows 'that there was as yet no division between rhêtorikê and grammar'. Apparently, he assumes that it was as much Protagoras' goal to say something about the uses of language (rhetoric) as about its formal aspects (grammar).
} 


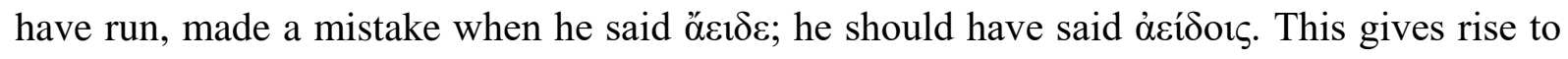
the assumption that the $\pi v \theta \mu \varepsilon ́ v \varepsilon \varsigma \lambda$ ó $\gamma \omega v$ map onto typical functions of the four grammatical moods or, more accurately, onto the only 'true' function of each mood; Protagoras' argument depends on a generalization of the observation that the imperative is typically used in orders to the claim that the imperative can or should only be used in orders. ${ }^{35}$ The following associations

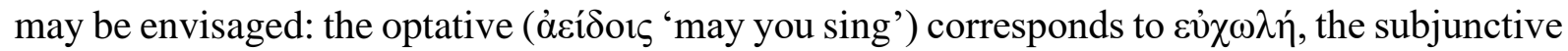

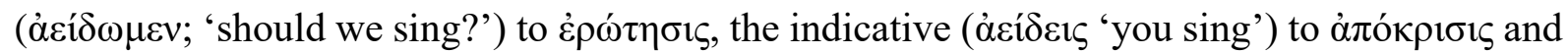
the imperative (ä $\varepsilon 1 \delta \varepsilon$ 'sing!') to $\dot{\varepsilon} v \tau \circ \lambda \eta$.

One indication are the names which Protagoras gave to the moods. 'Prayer' ( $\varepsilon \cup \chi^{\prime} \omega \lambda \eta$ )

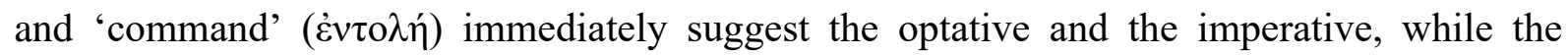
indicative is the prototypical mood of (a standard type of) 'answer' ( $\alpha$ ó $\kappa \rho \imath \sigma 1 \zeta) .{ }^{36}$ Only the

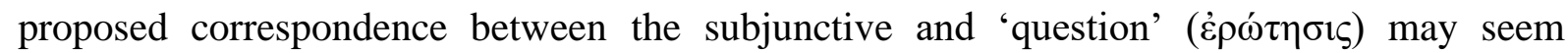
problematic. ${ }^{37}$ For although several scholars have guessed that the sophist must have had the subjunctive in deliberative questions in mind, this solution at first sight looks like a cop-out, because the use of the subjunctive in this environment hardly represents a typical usage; later

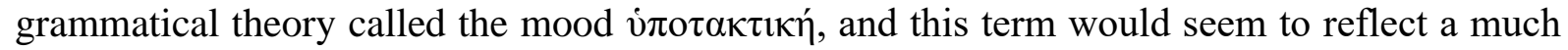
more central characteristic of the subjunctive, namely its use in subordinate clauses.

\footnotetext{
${ }^{35}$ So Rademaker (2013) 92-3.

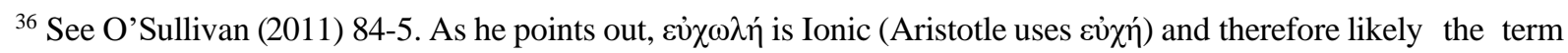

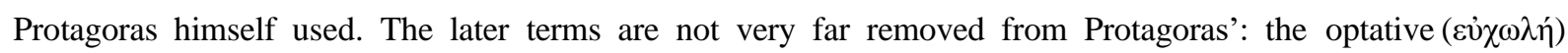

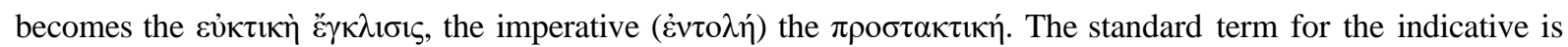
ópıбıкฑ́, which can be understood as either 'defining' or 'specifying', and these may also be the types of 'answer' Protagoras had in mind ('What is Socrates?' - 'Socrates is a man'; 'What is Socrates doing?'-'Socrates is teaching').

37 Gomperz (1922) 367 accepted the correspondence, though diagnosing 'einen Anflug von Gewaltsamkeit'.
} 
Having said that, we think that it is actually only natural that Protagoras should have turned to the deliberative subjunctive. What needs to be kept in mind is that the use of the subjunctive in subordinate clauses is nearly always obligatory, that is, determined by the syntactic rules of the language and not immediately by its semantics. This makes it difficult to assign a specific meaning to the subjunctive in this environment; one cannot, for instance, replace the subjunctive with another mood to see how the meaning changes, because in most cases all one will have produced is something ungrammatical and meaningless. It is reasonable to assume, therefore, that a pioneering linguist like Protagoras focused on environments in which mood choice does have immediate consequences for the meaning of sentences, that is, on main clauses. If this is correct, he could have had three uses in mind: ${ }^{38} 1$ ) the deliberative

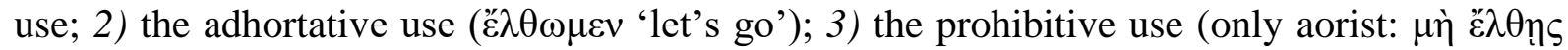
'don't go'). The last two of these were unsuitable because of their jussive force, which Protagoras (naturally) assigned to the imperative. Moreover, the criterion of substitution is almost as useless in the case of the prohibitive subjunctive as in the case of subordinate clauses; ${ }^{*} \mu \grave{\eta} \tilde{\eta} \lambda \theta \varepsilon \varsigma$ and * $\mu \grave{\eta} \dot{\varepsilon} \lambda \theta \dot{\varepsilon}$ are both ungrammatical. Only the deliberative subjunctive could therefore serve to complete the system.

\section{$4 \quad$ Further grammatical distinctions?}

Since the scope of Protagoras' grammatical analyses thus encompassed both the fundamental category of nominal gender and the equally fundamental category of verbal mood, we may wonder if he did not also consider the most important counterpart of each, that is, nominal case and verbal tense, respectively. ${ }^{39}$ As for the former, there is no positive evidence and, given the

\footnotetext{
${ }^{38}$ Cf. Rijksbaron (2002) 39-40.

${ }^{39}$ Alongside tense and mood, modern descriptions of Ancient Greek of course pay equal attention to aspect, but
} 
way in which Aristotle critically exposes the disregard for the nominative vs. accusative distinction in the sophistic $\varepsilon \dot{\lambda} \varepsilon \gamma \gamma \chi 01$ (cf. Section 2.4), this need not be a coincidence: perhaps Protagoras really had nothing to say on the matter. In the light of what has just been remarked about mood distinctions, this would not be surprising. Unlike the substitution of one mood by another in main clauses, or indeed the substitution of one gender by another in the case of pairs

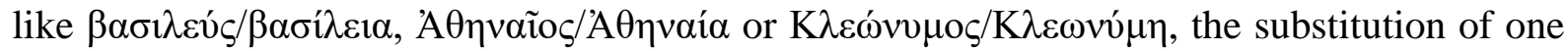
case by another would not, in a standard sentence, produce a semantically different, but grammatically still acceptable outcome. Even a sophist cannot readily attack Homer for saying

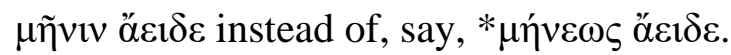

With tense, on the other hand, the situation is similar to the one with mood. There would

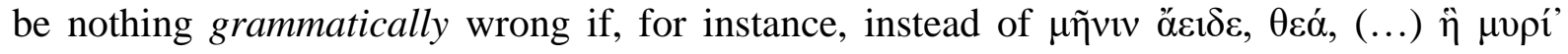

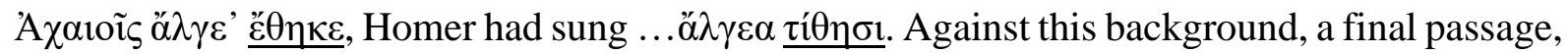
this time from Diogenes Laertius' sketch of Protagoras' life, deserves attention:

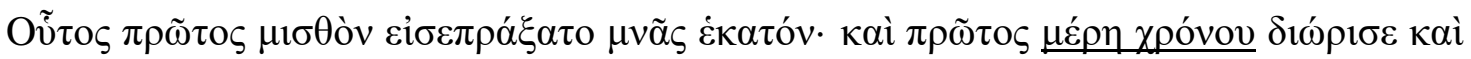

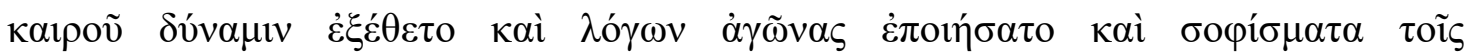
$\pi \rho \alpha \gamma \mu \alpha \tau$ $9.52=$ Protagoras DK 80 A $1.52=$ Radermacher B III $24=$ Protagoras D20 Laks/Most)

He was the first to exact a fee of one hundred minae, and the first to distinguish parts of time, to set forth the power of kairos, to institute contests in debating, and to teach rival

\footnotetext{
in antiquity (and until fairly recently) the latter category - and notably the status of the aorist - was subsumed

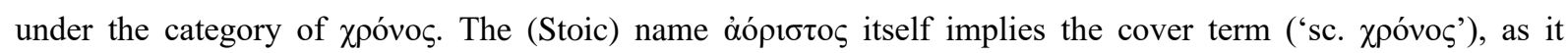
designates a 'tense' form that is 'undefined' with regard to the durative ( $\pi \alpha \rho \alpha \tau \alpha \tau \iota \kappa o ́ \varsigma)$ vs. completed ( $\sigma v v \tau \varepsilon \lambda \iota \kappa o ́ \varsigma)$

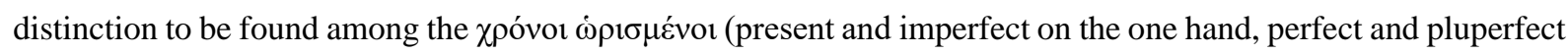
on the other) (cf. Steinthal (1890-91) 2.302-3, Wackernagel (1926) 15).
} 
pleaders the tricks of their trade. And, setting aside the meaning, he argued with a view to the [form of the] word.

The difficult last clause, if understood like this, rather neatly encapsulates Protagoras' formal take on language.$^{40}$ Here, however, we focus on the preceding clause, with its reference to $\mu \varepsilon ́ p \eta$ $\chi \rho$ óvov. This has been widely understood as hinting at a distinction of tenses, ${ }^{41}$ and not just because it is so reminiscent of terms like Aristotle's $\mu \varepsilon \dot{\rho} \rho \lambda \lambda \varepsilon_{\varepsilon} \xi \varepsilon \omega \varsigma$ 'parts of expression' (Arist. Poet. $20=1456 \mathrm{~b} 20-57 \mathrm{a} 30$, which discusses word classes as well as other units such as syllables

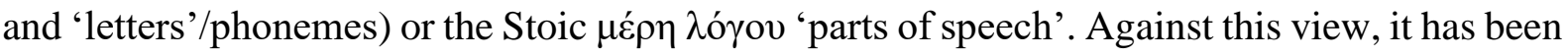
observed that Aristotle was the first to analyze the encoding of time in the verb (Arist. Int. 16b6-

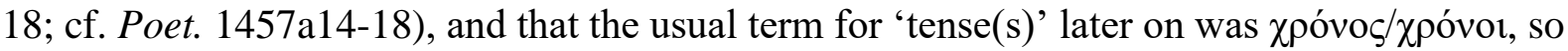

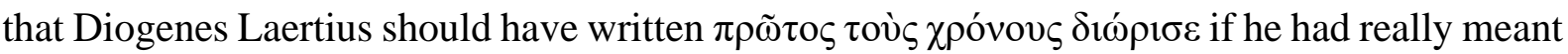
to refer to the grammatical feature. ${ }^{42}$ Neither of these objections is cogent. The first is a mere petitio principii, and the second overlooks that an alternative formulation like the one just cited might have misleadingly suggested that Protagoras already came up with the full inventory of tenses with which later grammarians operate; that, however, need not be the case. If the most

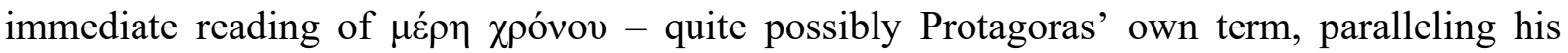
$\pi v \theta \mu \varepsilon ́ v \varepsilon \varsigma \lambda o ́ \gamma \omega v$ for what were later called $\dot{\varepsilon} \gamma \kappa \lambda i ́ \sigma \varepsilon ı \varsigma$ 'moods' - is the simple tripartite division

\footnotetext{
40 Translations vary: Laks/Most (2016) 99 ('Disregarding the meaning, he discussed the word') seem to think of a signifié/signifiant dichotomy, as implied above (cf. Gigante (1976) 374, Graham (2010) 2.693); Hicks (1925) 465 ('he neglected the meaning in favour of verbal quibbling') reads a moral judgment into Diogenes' remark (cf. Mensch (2018) 461).

${ }^{41}$ Thus, for example, Zeller (1920) 1417, Hicks (1925) 465, Untersteiner (1961) 19, Graham (2010) 2.693, Laks/Most (2016) 47, Novokhatko (2020) 109-10; cf. Dunn (2001) 547-8 n. 1 with further references.

${ }^{42}$ Dunn (2001) 548, with reference to the general argument of Fehling (1965) 212-17, and especially Pfeiffer (1968) 38-9, 77, 245.
} 
into past, present and future, ${ }^{43}$ it is conceivable that that is exactly what Protagoras also saw to be reflected in grammar; for Dunn (2001) 548-9 rightly stresses that Diogenes cannot have meant that Protagoras was the first to notice the existence (in human experience) of a past, present and future as such - which would be banal -, nor that Protagoras is likely to have come up with the complex differentiations later philosophers make between the ontological nature of the present as opposed to the past and future. Given the context in which it occurs, Diogenes' note must refer to something that either left a striking impression (cf. the astronomical fee, mentioned before) or represented an intellectual innovation with which Diogenes' educated lay readers were familiar themselves (cf. the rhetorical importance of the kaıpós, mentioned afterwards). ${ }^{44}$ The recognition that the division of time into past, present and future is somehow reflected in verbal morphology would fit this requirement, and given the prominence and relative complexity of tense distinctions in Greek it would also stand to reason that Diogenes chose to highlight this aspect rather than the (parallel) discovery of mood, let alone nominal gender; after all, ever since Aristotle at least, time (and hence tense) was known to have a special defining status when it came to the understanding of verbs (cf. Arist. Int. 16b6-7, $\dot{\rho} \tilde{\eta} \mu \alpha$

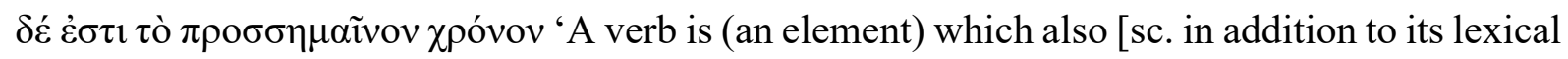
meaning] signifies time').

To this, one might of course still object that, while there is no better suited alternative for

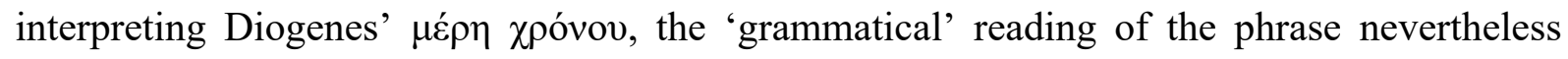
remains in the air as long as there is no corroborating evidence of the kind we came across when dealing with genders and moods. However, there may be one piece of information that does

\footnotetext{
${ }^{43}$ Cf. Dunn (2001) 548, with parallels in (late) philosophical literature.

${ }^{44}$ This also speaks against the unorthodox idea of Gunning (1915) 114 according to whom a 'lesson timetable' might be meant. On the connection of the notion of kaıpó $\varsigma$ with the analysis of styles and registers and its origins among the sophists, see Willi (2010) 304; cf. also Trédé (1992) 247-50.
} 
deserve a further look in this context. Consider again the Diogenes passage according to which Protagoras 'was the first to divide speech into four kinds - prayer, question, answer, command (others say into seven: narration, question, answer, command, report, prayer, calling), which he even named "foundations of speech". In our earlier discussion we did not dwell on the parenthetical remark, and it is true that the Greek text need not mean that 'others' claimed an alternative seven-fold division for Protagoras himself. If need be, it might also be shorthand for 'while others subsequently came up with a seven-fold division'. Even so, the grammatically most straightfoward reading is the former, and it therefore invites reflection.

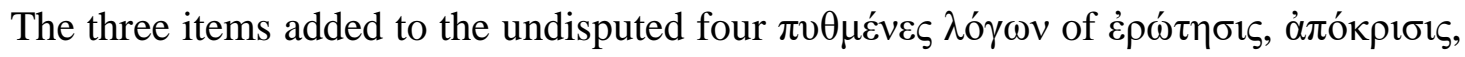

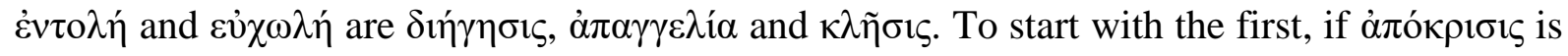
to be identified with the indicative, as argued above, we may ask in what way it could make

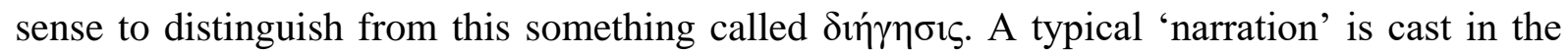
indicative just as much as a typical 'answer' is. However, what does separate a standard 'narration' from the kind of defining or specifying 'answer' Protagoras is likely to have had in mind ('Socrates is a man', 'Socrates is teaching'; cf. Section 3) is its past tense ('Socrates taught/was teaching'). Seen in this light, and considering the nomenclatory principle Protagoras

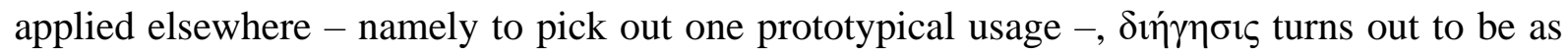
sensible a proto-grammatical term for 'past tense' as $\varepsilon \cup ่ \chi \omega \lambda \eta$ is for the 'optative', for example.

Given a threefold division of past/present/future, that would then at first seem to leave $\dot{\alpha} \pi \alpha \gamma \gamma \varepsilon \lambda i \dot{\alpha}$ and $\kappa \lambda \tilde{\eta} \sigma \iota \varsigma$ for the present and future respectively. Yet, $\dot{\alpha} \pi \alpha \gamma \gamma \varepsilon \lambda i{ }^{\alpha} \alpha$ means 'report' and the standard tense in a report is the past no less than in a narration. Moreover, a 'calling' of whatever sort ( $\kappa \lambda \tilde{\eta} \sigma \iota \varsigma)$ is also not something one would easily associate with either a present or a future: the imperative might provide a better fit, but that slot is already occupied by $\dot{\varepsilon} v \tau \mathrm{\lambda} \lambda \dot{\eta}$.

At this point, however, two further observations become relevant. The first concerns the textual transmission. The most important manuscripts of Diogenes $\left(\mathrm{BP}^{1} \mathrm{~F}\right)$ as well as the corresponding Suda entry ( $\pi$ 3122) give $\dot{\varepsilon} \pi \alpha \gamma \gamma \varepsilon \lambda i ́ \alpha v$, while $\dot{\alpha} \pi \alpha \gamma \gamma \varepsilon \lambda i ́ \alpha v$ only occurs in 
manuscripts that have no independent authority and was probably introduced by emendation. ${ }^{45}$ And just as $\dot{\varepsilon} \pi \alpha \gamma \gamma \varepsilon \dot{\varepsilon} \lambda \lambda \omega$ means 'announce, offer, promise', the basic meaning of $\dot{\varepsilon} \pi \alpha \gamma \gamma \varepsilon \lambda i$ is 'announcement, promise' - which is a rather neat match for the prototypical function of future tense forms. The second observation concerns the classification itself. From our perspective, tense and mood are independent variables, but at the proto-grammatical stage we are dealing with this need not have been so obvious, not least because the grammatical categories were so much (terminologically) intertwined with corresponding pragmatic functions. Thus, if

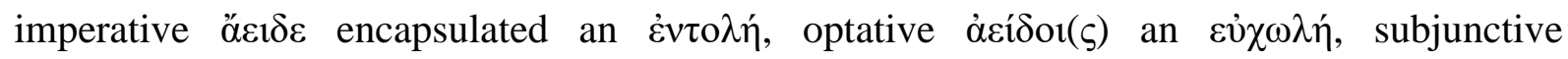

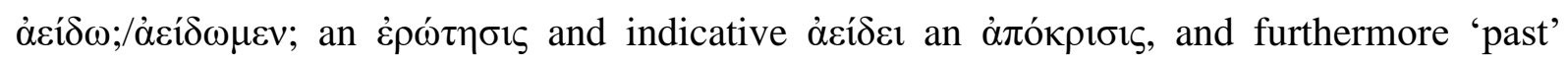

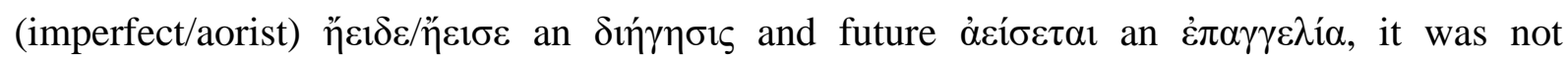
immediately clear that present àcí $\delta \varepsilon 1$ needed a second, temporal, label as well. Instead,

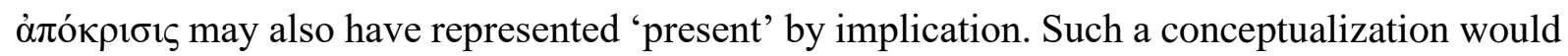
not be out of line with what we come across later, when Aristotle (Int. 16b9-10, 16-17) treats

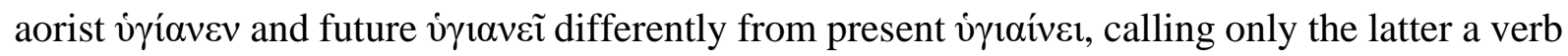
( $\dot{\rho} \tilde{\eta} \mu \alpha$ ), but the former two merely inflections of the verb (ov̉ $\dot{\rho} \tilde{\eta} \mu \alpha \dot{\alpha} \lambda \lambda \dot{\alpha} \pi \tau \tilde{\omega} \sigma \iota \varsigma \dot{\rho} \eta \dot{\mu} \mu \tau$ os): here too, then, the present is taken as a base form with a different status from the past and future forms.

If this is accepted, we are only left with the seventh item, $\kappa \lambda \tilde{\eta} \sigma ı \varsigma$. One possibility - but hardly more than that - would be to remember that the later grammatical tradition, as codified in Dionysius Thrax' $\tau \dot{\chi} \chi v \eta$ (Grammatici Graeci 1.1, p. 47 Uhlig), treated the infinitive as a fifth mood, hence assigned it a status in parallel with the finite forms of the verb. If something like this was already happening here, Protagoras just might have been thinking of syntactically autonomous imperatives in jussive environments, including 'invitational/cletic' ones (cf. e.g.

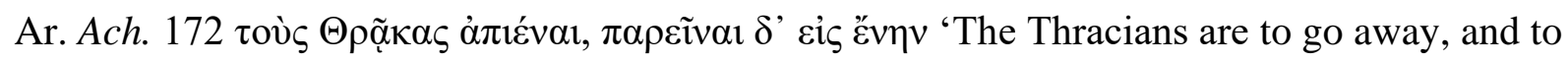

\footnotetext{
${ }^{45}$ See the apparatus of Dorandi (2013).
} 
be back the day after tomorrow', Ar. Vesp. $937 \mu \alpha{ }^{\prime} \rho \tau \nu \rho \alpha \varsigma \pi \alpha \rho \varepsilon i ̃ v \alpha l$ 'as witnesses are to present themselves'). With this addition, the seven-fold system of form/function mappings would thus gain a considerable degree of internal coherence - though for some readers that very fact might perhaps constitute an argument against its historical plausibility. Be that as it may, the upshot of the preceding discussion is a different one anyway. To deny, in the light of what our elusive sources tell us, that Protagoras can have reflected on verbal categories beyond mood is in no way a safer position to take than to accept that he may very well have done so.

\section{Conclusion}

It hardly needs stressing that much remains unclear and uncertain when we try to reconstruct the earliest stages of Greek linguistic thought. However, against the nowadays prevalent view according to which Protagoras' endeavours in the domain of grammar were confined to inconsequential side remarks, it has here been argued that all the evidence we have rather points to a fairly sophisticated approach to categories such as nominal gender and verbal mood, which - for the first time - took into account the formal expression of these. In particular, there is no reason to think that Protagoras' teaching on gender was based on haphazard semantic criteria rather than systematic formal ones, or that his $\pi v \theta \mu \varepsilon ́ v \varepsilon \varsigma \lambda$ ó $\omega \omega v$ were identified without reference to modal morphology. Moreover, a tentative case can even be made for at least a basic tense differentiation having been attempted alongside the classification of moods. That all these matters were ultimately meant to feed into literary exegesis, and from there into an understanding of how 'to guarantee the greatest possible degree of clarity in the use of language', ${ }^{46}$ may well be true,

\footnotetext{
${ }^{46}$ As Classen (1976) 226 puts it. Where Protagoras' linguistic doctrines were to be found in writing we do not know, not least because the list of Protagoras' works given by Diogenes Laertius (9.55) is evidently incomplete and because 'O $\rho$ oź $\pi \varepsilon 1 \alpha$ need not have been (...) the title of a book, as many scholars assume' (Classen (1976)
} 
but it would be wrong to conclude from this that Protagoras could not also be interested in the structure of language in its own right. To be sure, others - including Aristotle, the Stoics and the Alexandrian grammarians - eventually went much further than he had done; but that is what happens to any pioneer and must not make us undervalue the substantial achievements we are still able to piece together from a tradition and transmission that has been less generous than it could have been to one of the towering intellectuals of the classical age. ${ }^{47}$

\section{References}

Austin, C., Olson, S. D. (2004) Aristophanes: Thesmophoriazusae. Edited with introduction and commentary, Oxford.

Blank, D. L. (1985) 'Socratics versus sophists on payment for teaching', Classical Antiquity 4, 1-49.

Bonitz, H. (1870) Index Aristotelicus, Berlin

Classen, C. J. (1976) 'The study of language amongst Socrates' contemporaries', in C. J. Classen (ed.) Sophistik, Darmstadt, 215-47.

Corradi, M. (2012) Protagora tra filologia e filosofia. Le testimonianze di Aristotele, Pisa/Rome.

Di Cesare, D. (1991) 'Die Geschmeidigkeit der Sprache. Zur Sprachauffassung und Sprachbetrachtung der Sophistik', in P. Schmitter (ed.) Sprachtheorien der abendländischen Antike, Tübingen, 87-117.

Dietz, K.-M. (1976) Protagoras von Abdera. Untersuchungen zu seinem Denken, Bonn.

Dorandi, T. (2013) Diogenes Laertius. Lives of eminent philosophers, Cambridge.

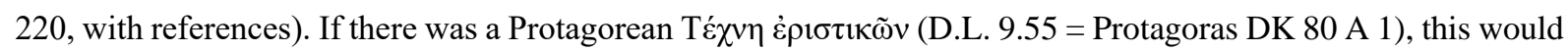
be one possibility (cf. Classen (1976) 225), but so would be his À $\lambda \theta \varepsilon 1 \alpha$ (Pfeiffer (1968) 37, 280).

${ }^{47} \mathrm{We}$ would like to thank the Amsterdamse Hellenistenclub and audiences in Heidelberg, Oxford and Pennsylvania for their comments on earlier versions of this paper and Felix Budelmann and Jonathan Griffiths for answering specific queries; we also thank two anonymous referees for their incisive feedback. 
Dorion, L.-A. (1995) Aristote: Les réfutations sophistiques. Introduction, traduction et commentaire, Paris.

Dunn, F. (2001) 'Protagoras and the parts of time', Hermes 129, 547-50.

Fehling, D. (1965) 'Zwei Untersuchungen zur griechischen Sprachphilosophie: 1. Protagoras und die

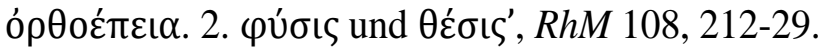

Gigante, M. (1976) Diogene Laerzio: Vite dei Filosofi, vol. ii: Libri VIII-X, Roma/Bari.

Gomperz, T. (1922) Griechische Denker. Eine Geschichte der antiken Philosophie I (4th edn.), Leipzig.

Graham, D. W. (2010) The texts of early Greek philosophy: The complete fragments and selected testimonies of the major Presocratics (2 vols.), Cambridge.

Guthrie, W. K. C. (1971) The sophists, Cambridge.

Gunning, C. P. (1915) De sophistis Graeciae praeceptoribus, Amsterdam.

Hecquet, M. (2019) Aristote: Les réfutations sophistiques. Introduction, édition du texte grec et commentaire, Paris.

Hicks, R. D. (1925) Diogenes Laertius: Lives of eminent philosophers, vol. ii: Books 6-10 (Loeb Classical Library 185), Cambridge, Mass.

Janse, M. (2020) 'Sex and agreement: (Mis)matching natural and grammatical gender in Greek', Keria 22 (2), 25-55.

Kerferd, G. B. (1981) The Sophistic movement, Cambridge.

Kraus, M. (1987) Name und Sache. Ein Problem im frühgriechischen Denken, Amsterdam.

Laks, A., Most, G. W. (eds.) (2016) Early Greek philosophy, vol. viii: Sophists, part I (Loeb Classical Library 531), Cambridge, Mass.

Lana, I. (1950) Protagora, Turin.

Lougovaya, J., Ast, R. (2004) 'Menis and Pelex. Protagoras on solecism', CQ 54, 274-7.

Mensch, P. (trans.) (2018) Diogenes Laertius: Lives of the eminent philosophers (ed. J. Miller), Oxford/New York. 
Most, G. W. (1986) 'Sophistique et herméneutique', in B. Cassin (ed.) Positions de la sophistique, Paris, 233-45.

Murray, G. (1946) 'The beginnings of grammar, or first attempts at a science of language in Greece', in G. Murray, Greek studies, Oxford, 171-91.

Novokhatko, A. (2020) 'The origins and growth of scholarship in Pre-Hellenistic Greece', in F. Montanari (ed.) History of ancient Greek scholarship: From the beginnings to the end of the Byzantine age, Leiden/Boston, 9-131.

O'Sullivan, N. (2011) “"It would be the time to discuss the optatives”. Understanding the syntax of the optative from Protagoras to Planudes', Antichthon 45, 77-112.

Pfeiffer, R. (1968) History of classical scholarship: From the beginning to the end of the Hellenistic age, Oxford.

Rademaker, A. (2013) 'The most correct account: Protagoras on language', in J. M. van Ophuijsen, M. van Raalte, P. Stork (eds.) Protagoras of Abdera: The man, his measure, Leiden, $87-111$.

Rijksbaron, A. (1991) Aristotle, verb meaning and functional grammar: Towards a new typology of states of affairs, Amsterdam.

Rijksbaron, A. (2002) The syntax and semantics of the verb in Classical Greek: An introduction (3rd edn.), Amsterdam.

Schenkeveld, D. M. (1984) 'Studies in the history of ancient linguistics II. Stoic and Peripatetic kinds of speech act and the distinction of grammatical moods', Mnemosyne 37, 291-353.

Schreiber, S. G. (2003) Aristotle on false reasoning: Language and the world in the Sophistical Refutations, Albany.

Siebenborn, E. (1976) Die Lehre von der Sprachrichtigkeit und ihren Kriterien. Studien zur antiken normativen Grammatik, Amsterdam.

Sluiter, I. (1990) Ancient grammar in context. Contributions to the study of ancient linguistic thought, Amsterdam. 
Steinthal, H. (1890-91) Geschichte der Sprachwissenschaft bei den Griechen und Römern (2nd edn., 2 vols.), Berlin.

Stern, H. H. (1983) Fundamental concepts of language teaching: Historical and interdisciplinary perspectives on applied linguistic research, Oxford.

Tell, H. P. (2009) 'Wisdom for sale? The sophists and money', CPh 104, 13-33.

Trédé, M. (1992) Kairos: L'à-propos et l'occasion (Le mot et la notion, d'Homère à la fin du IVe siècle avant J.-C.), Paris.

Untersteiner, M. (1961) Sofisti: Testimonianze e frammenti, fasc. i: Protagora e Seniade, Firenze.

Wackernagel, J. (1926, 1928) Vorlesungen über Syntax mit besonderer Berücksichtigung von Griechisch, Lateinisch und Deutsch (2nd edn., 2 vols.), Basel.

Willi, A. (2010) 'Register variation', in E. J. Bakker (ed.) A companion to the Ancient Greek language, Chichester, 297-310.

Zeller, E. (1920) Die Philosophie der Griechen in ihrer geschichtlichen Entwicklung dargestellt. Erster Teil: Allgemeine Einleitung, Vorsokratische Philosophie. Zweite Hälfte (6th edn., ed. W. Nestle), Leipzig. 